\title{
Synthesis of second-generation self-assembling Gemini Amphiphilic Pseudopeptides
}

Ahmed H. Lotfallah, ${ }^{a,}$ M. Isabel Burguete, ${ }^{\mathrm{a}}$ Ignacio Alfonso ${ }^{\mathrm{b}, *}$ and Santiago V. Luis ${ }^{\mathrm{a}, *}$ ${ }^{a}$ Department of Inorganic and Organic Chemistry, ESTCE, Universitat Jaume I, Avda. Sos Baynat, $s / n$, 12071, Castellón, Spain.E-mail: luiss@uji.es

${ }^{b}$ Department of Biological Chemistry, IQAC-CSIC, Jordi Girona 18-26, 08034, Barcelona, Spain. E-mail: ignacio.alfonso@iqac.csic.es

'Present address: Department of Pharmaceutical Chemistry, Faculty of Pharmacy, Sinai University, 16020, El-Arish, Egypt

Keywords: Gemini pseudopeptides, amphiphiles, self-assembly

Corresponding author: Santiago V. Luis,

Department of Inorganic and Organic Chemistry, ESTCE, Universitat Jaume I, Avda. Sos Baynat, s/n, 12071, Castellón, Spain. E-mail: luiss@uji.es

Phone: +34964 728239

Fax:+34 964728215 


\title{
Synthesis of second-generation self-assembling Gemini Amphiphilic Pseudopeptides
}

\author{
Ahmed H. Lotfallah, ${ }^{a, c}$ M. Isabel Burguete, ${ }^{a}$ Ignacio Alfonso ${ }^{\mathrm{b}, *}$ and Santiago V. Luis ${ }^{\mathrm{a}, *}$ \\ ${ }^{a}$ Department of Inorganic and Organic Chemistry, ESTCE, Universitat Jaume I, Avda. Sos Baynat, s/n, \\ 12071, Castellón, Spain.E-mail: luiss@uji.es \\ ${ }^{b}$ Department of Biological Chemistry, IQAC-CSIC, Jordi Girona 18-26, 08034, Barcelona, Spain. E-mail: \\ ignacio.alfonso@iqac.csic.es
}

'Present address: Department of Pharmaceutical Chemistry, Faculty of Pharmacy, Sinai University, 16020, El- Arish, Egypt

\begin{abstract}
Hypothesis: The structural modularity of Gemini Amphiphilic Pseudopeptides (GAPs) allows the tuning of the self-assembling properties by slight modifications in the chemical structures. We hypothesized that the introduction of a flexible linker containing a central nitrogen atom in bipodal and tripodal GAPs would improve their self-assembly properties in aqueous media.

Experiments: After preparation of the corresponding GAPs, a combination of SEM, TEM and AFM techniques were used to study the morphology of the self-assembled structures in different media. The solution structures in non-aggregated states were also analyzed by combining NMR, UV and CD studies. The transition from the non-aggregated species to the hierarchical self-assembly was monitored by ATR FT-IR spectroscopy, while the critical aggregation concentration in water was determined by fluorescence spectroscopy.

Findings: The formation of different morphologies (vesicles or fibers) highly depends on the polarity and the $\mathrm{pH}$ of the medium. A reasonable mechanism for the self-assembly has been established in agreement with the experimental techniques used, where the protonation of the nitrogen in the linker must play a key role. In general, the obtained GAPs showed an improved formation of vesicles in aqueous media (different $\mathrm{pH}$ or ionic strength) with potential applications in biomedicine and drug delivery.
\end{abstract}

Keywords: Gemini pseudopeptides, amphiphiles, self-assembly 


\section{Introduction}

The spontaneous self-assembly of molecules leading to well-ordered nano- or micro-structures is a hot topic in supramolecular chemistry with interesting applications in materials science and chemical biology.[1-18] However, the full understanding of the forces and rules governing the process is still incomplete and requires the study of systematically designed structures with controlled and modular chemical variations.[19-24] Among the different varieties of selfassembling molecules reported to date, those showing amphiphilic properties are especially interesting since they can behave in dual manner when media are changed from relatively non-polar organic solvents to buffered aqueous solutions.[25-34] Moreover, the possibility of protonation/deprotonation producing differences in the self-assembling properties is an additional value.[35-39] These facts make amphiphilic protonable compounds very appealing for the design of delivery systems and stimuli responsive materials.[40-43] Regarding the available structural motifs for building such structures, the ones based on amino acids and peptides are especially versatile, since the natural amino acid side chains cover a wide polarity range and many different functional groups accessible for chemists. In addition, peptide-like molecules are easy to synthesize and they usually show low unspecific toxicity and good biocompatibility.[44-54] However, the fast biodegradation rate of the peptide bond represents the main drawback of these molecules. A possible solution would be the combination of peptide-like moieties with non-peptidic artificial structures, which will implement an increased stability in biological media. To this aim, previous studies in our group with pseudopeptidic molecules have shown they possess excellent chemical, structural and biological properties, as well as some interesting self-assembly abilities. In this field, we have previously reported amphiphilic derivatives with structural flexibility and responsiveness to simple stimuli, able to render different self-assembled nano- and micro-structures.[38-41, 55,56] The obtained ultrastructures strongly depend on the fine balance of polar and hydrophobic interactions between molecules and with the environment, which can be modulated by tailor-made chemical and structural variations. We coined these molecules as Gemini Amphiphilic Pseudopeptides (or just GAPs), as an overall description of their structural features (general formula in Figure 1).[38-40] Some of these GAPs organize in self-assembled microstructures with interesting responsive properties. However, the aqueous compatibility of the previously reported GAP molecules was somehow limited for biomedical applications. In this contribution, we report on the preparation and full study of a second-generation GAPs with more flexible and easily protonable polar spacers based on bis(ethyleneamine) and tris(ethyleneamine), which provides a first example of a tripodal GAP for increasing the modularity and aggregation 
capabilities (Figure 1). The corresponding self-assembly properties have been analyzed with the combination of different experimental techniques at the different stages of the selfassembly process: from pure solutions to solid-state aggregates.

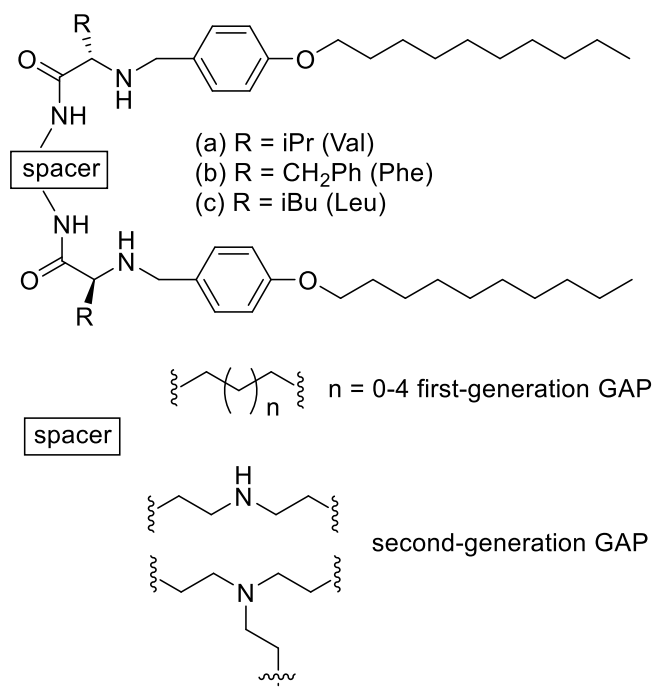

Figure 1. General structure of first- and second-generation GAPs

\section{Materials and Methods}

\subsection{General characterization protocols}

NMR spectroscopy: The NMR experiments were carried out on a Varian INOVA500 spectrometer $\left(500 \mathrm{MHz}\right.$ for ${ }^{1} \mathrm{H}$ and $125 \mathrm{MHz}$ for ${ }^{13} \mathrm{C}$ ). Chemical shifts for all the compounds are reported in ppm ( $\delta$ ) using TMS as a reference.

Infrared spectroscopy: FT-IR spectra were acquired in a JASCO 6200 equipment having a MIRacle Single Reflection ATR Diamond/ZnSe accessory. The raw IR data were processed with the JASCO spectral manager software and the deconvolution of the bands was performed with Origin ${ }^{\circledR}$ software, using Gaussian-shaped ideal peaks.

Mass spectrometry: High resolution Mass Spectra were recorded on a hybrid QTOF I (quadrupole-hexapole-TOP) mass spectrometer with an orthogonal Z-spray- electrospray interface (Micromass, Manchester, UK). The desolvation gas as well as the nebulizing gas was nitrogen at a flow of $700 \mathrm{~L} / \mathrm{h}$ and $20 \mathrm{~L} / \mathrm{h}$ respectively. The temperature of the source block was set to $120^{\circ} \mathrm{C}$ and the desolvation temperature to $150{ }^{\circ} \mathrm{C}$. A capillary voltage of 3.5 and $3.3 \mathrm{kV}$ respectively was used in the positive and negative scan mode. The cone voltage was typically set to $20 \mathrm{~V}$ to control the extent of fragmentation of the identified ions. Sample solutions were infused via a syringe pump directly connected to the ESI source at a flow rate of $10 \mathrm{~L} / \mathrm{min}$. The observed isotopic pattern of each intermediate perfectly matched the theoretical isotope pattern calculated from their elemental composition using the MassLynx 4.0 program. Mass spectra were also recorded on a Micromass Quattro LC spectrometer equipped with an electrospray ionization source and a triple-quadrupole analyzer.

Elemental analysis: Carbon, hydrogen and nitrogen elemental analyses were carried out in a CHN Euro EA 3000 elementary analyzer. 
Melting point: melting points were measured using a Melting Point Stuart SMP10 apparatus.

Rotatory power: rotatory power was determined with a Jasco DIP-1000 polarimeter, and a cylindrical glass cell model CG3-50, $3.5 \mathrm{~mm}$ diameter and $50 \mathrm{~mm}$ a length.

Scanning Electron Microscopy (SEM): Scanning Electron Microscopy was performed either in a LEO 440 or in a JEOL $7001 \mathrm{~F}$ microscope with a digital camera Samples were conventionally coated with Pd by Polaron SC7610 metalizing Fisons instrument before the measurement.

Transmission Electron Microscopy (TEM): Transmission Electron Microscopy was carried out in a JEOL 2100 microscope with a digital camera at $120 \mathrm{KV}$.

Atomic Force Microscopy (AFM): Atomic Force Microscopy was carried out in a JEOL JSPM 5200 scanning probe microscope with a digital camera.

UV-visible absorption spectroscopy: UV-visible absorption measurements were made using a Hewlett-Packard 8453 spectrophotometer. All the samples were measured in aerated conditions, unless otherwise stated.

Steady-state fluorescence spectroscopy: Steady-state fluorescence spectra were recorded in a Spex Fluorog 3-11 equipped with a $450 \mathrm{~W}$ xenon lamp. Fluorescence spectra were recorded in the front face mode. All these samples were measured in aerated conditions, unless otherwise stated.

UV and CD spectroscopy: Spectra were recorded with a JASCO J-810 spectropolarimeter at rt. The normalized $C D$ spectra were obtained by transforming the molar circular dichroic absorption data $\left(\Delta \varepsilon, \mathrm{cm}^{2} \mathrm{mmol}^{-1}\right)$ using the formula: $\Delta \varepsilon=\theta /(32980 \mathrm{Cl})$, in which $\theta$ is the measured ellipticity (in mdeg), $C$ is the concentration (in $M$ ) and $I$ is the path length (in $\mathrm{cm}$ ). Molar extinction coefficients of the UV spectra were obtained by linear regression between the measured absorbance and the sample concentration.

Optical Microscopy: Such Studies were performed using normal light and polarized light with an Olympus BX51 apparatus with a thermostated plate being capable of heating to $600{ }^{\circ} \mathrm{C}$.

Differential Scanning Calorimetry (DSC): DSC was carried out in DSC6 Perkin Elmer.

\subsection{Synthetic protocols and structural characterization}

Synthesis of 2a: N-Cbz-L-Valine (25 g, $99.49 \mathrm{mmol})$ and N-hydroxysuccinimide $(11.45 \mathrm{~g}, 99.49$ mmol) were dissolved in dry THF at $0{ }^{\circ} \mathrm{C}$. Once a clear solution had been obtained, DCC (20.52 $\mathrm{g}, 99.49 \mathrm{mmol}$ ) in anhydrous THF was added in drop wise manner, and the resulting solution was stirred at $0-5{ }^{\circ} \mathrm{C}$ for $3 \mathrm{~h}$. The dicyclohexylurea formed was filtered off and the filtrate was concentrated to dryness. The crude product was recrystallized from 2propanol to obtain the pure product. Yield $89 \%$; $\mathrm{mp} 118-120{ }^{\circ} \mathrm{C}$ (literature $\mathrm{mp}$ : $119-120$; [32a]); $[\alpha]_{D}^{25}=-20.1\left(c=0.1, \mathrm{CHCl}_{3}\right) ; \mathrm{IR}(\mathrm{KBr}) 3360,1741,1526 \mathrm{~cm}^{-1} ;{ }^{1} \mathrm{H} \mathrm{NMR}\left(300 \mathrm{MHz}, \mathrm{CDCl}_{3}\right)$ $\delta 1.02(\mathrm{~d}, 3 \mathrm{H}, J=7.4 \mathrm{~Hz}), 1.06(\mathrm{~d}, 3 \mathrm{H}, J=7.7 \mathrm{~Hz}), 2.31(\mathrm{~m}, 1 \mathrm{H}), 2.77(\mathrm{~s}, 4 \mathrm{H}), 4.66(\mathrm{dd}, 1 \mathrm{H}, J=4.7$, $8.9 \mathrm{~Hz}), 5.13(\mathrm{~s}, 2 \mathrm{H}), 5.43(\mathrm{~d}, 1 \mathrm{H}, J=9.5 \mathrm{~Hz}), 7.28-7.41(\mathrm{~m}, 5 \mathrm{H}) \mathrm{ppm} ;{ }^{13} \mathrm{C} \mathrm{NMR}\left(75 \mathrm{MHz}, \mathrm{CDCl}_{3}\right) \delta$ $17.2,18.7,25.5,31.5,57.4,67.2,128.0,128.1,128.3,135.8,155.6,167.5,168.6$ ppm; ESI-MS $m / z=349.3\left(\mathrm{M}+\mathrm{H}^{+}\right)$; Anal. Calcd. for $\mathrm{C}_{17} \mathrm{H}_{20} \mathrm{~N}_{2} \mathrm{O}_{6}: \mathrm{C}, 58.6 ; \mathrm{H}, 5.8 ; \mathrm{N}, 7.7$. found: $\mathrm{C}, 58.1 ; \mathrm{H}, 5.9 ; \mathrm{N}$, 8.0 .

Synthesis of 3a: To a clear solution of the $\mathrm{N}$-hydroxysuccinimide ester of $\mathrm{N}$-Cbz-L-valine (5.07 $\mathrm{g}, 14.55 \mathrm{mmol})$ in anhydrous DME $(150 \mathrm{~mL})$ at $0{ }^{\circ} \mathrm{C}$ was added dropwise diethelyenetriamine $(0.744 \mathrm{~g}, 7.21 \mathrm{mmol})$ dissolved in dry DME $(20 \mathrm{~mL})$. The reaction mixture was stirred at room temperature for $18 \mathrm{~h}$ and then was heated to $40-50{ }^{\circ} \mathrm{C}$ for $6 \mathrm{~h}$. The white solid was filtered and washed with cold water and cold methanol to exhaustively remove the $\mathrm{N}$-hydroxysuccinimide impurities. Yield 96\%; $\mathrm{mp} 174-177^{\circ} \mathrm{C} ;[\alpha]_{D}^{25}=11.39\left(c=0.1, \mathrm{CHCl}_{3}\right)$; IR (ATR) 3285, 2957, 1685, 1649, $1535 \mathrm{~cm}^{-1} ;{ }^{1} \mathrm{H}$ NMR (500 MHz, DMSO) $\delta 7.83(\mathrm{~s}, 2 \mathrm{H}), 7.38-7.23(\mathrm{~m}, 8 \mathrm{H}), 7.19(\mathrm{~d}, J=8.3 \mathrm{~Hz}$, 
$2 \mathrm{H}), 5.00(\mathrm{~s}, 4 \mathrm{H}), 3.76(\mathrm{~m}, 2 \mathrm{H}), 3.10(\mathrm{~m}, 4 \mathrm{H}), 2.47(\mathrm{~m}, 4 \mathrm{H}), 1.91(\mathrm{~m}, 2 \mathrm{H}), 0.82(\mathrm{~d}, J=6.1 \mathrm{~Hz}, 12 \mathrm{H})$ ppm; ${ }^{13} \mathrm{C}$ NMR (75 MHz, DMSO) $\delta 174.7,171.8,156.8,137.8,129.0,128.4,128.3,66.1,61.1$, 48.9, 30.9, 19.9, 18.9 ppm; HRMS (ESI-TOF) ${ }^{+}$Calcd. for $\mathrm{C}_{30} \mathrm{H}_{43} \mathrm{~N}_{5} \mathrm{O}_{6}\left(\mathrm{M}+\mathrm{H}^{+}\right)$570.3292. found 570.3296; Anal. Calcd. for $\mathrm{C}_{30} \mathrm{H}_{43} \mathrm{~N}_{5} \mathrm{O}_{6}$ : C, 63.3; $\mathrm{H}, 7.6 ; \mathrm{N}, 12.3$. found: $\mathrm{C}, 63.0 ; \mathrm{H}, 7.4 ; \mathrm{N}, 12.0$.

Synthesis of 7: Yield 94\%; $\mathrm{mp} 228-231^{\circ} \mathrm{C} ;[\alpha]_{D}^{25}=-39.7\left(c=0.01, \mathrm{CHCl}_{3}\right)$; IR (ATR): 3290, 2958, 2872, 1689, 1645, $1533 \mathrm{~cm}^{-1} ;{ }^{1} \mathrm{H}$ NMR (300 MHz, CDCl $) \delta 7.70(\mathrm{~s}, 3 \mathrm{H}), 7.22$ (d, J=5.5 Hz, 10H), $6.10(\mathrm{~d}, J=9.6 \mathrm{~Hz}, 3 \mathrm{H}), 4.98(\mathrm{q}, J=12.5 \mathrm{~Hz}, 6 \mathrm{H}), 4.16(\mathrm{t}, J=8.6 \mathrm{~Hz}, 3 \mathrm{H}), 3.26(\mathrm{~s}, 4 \mathrm{H}), 2.60(\mathrm{~s}, 5 \mathrm{H})$, 1.97 (s, 2H), 1.01 (dd, $\left.J=11.1,3.6 \mathrm{~Hz}, 15 \mathrm{H}) \mathrm{ppm} ;{ }^{13} \mathrm{C} \mathrm{NMR} \mathrm{(75} \mathrm{MHz}, \mathrm{CDCl}_{3}\right) \delta 172.75,157.22$, 136.42, 128.41, 127.51, 76.98, 66.55, 60.59, 55.09, 38.92, 31.14, 25.46, 19.28, 18.81 ppm; HRMS (ESI-TOF) ${ }^{+}$Calcd. for $\mathrm{C}_{45} \mathrm{H}_{63} \mathrm{~N}_{7} \mathrm{O}_{9}\left(\mathrm{M}+\mathrm{H}^{+}\right)$846.4766. found 846.4763; Anal. Calcd. for $\mathrm{C}_{45} \mathrm{H}_{63} \mathrm{~N}_{7} \mathrm{O}_{9}: \mathrm{C}, 63.9 ; \mathrm{H}, 7.5 ; \mathrm{N}, 11.6$. found: $\mathrm{C}, 63.6 ; \mathrm{H}, 7.5 ; \mathrm{N}, 11.9$.

Synthesis of 4a: A clear solution of the compound $3 \mathrm{a}(3.2 \mathrm{~g}, 5.62 \mathrm{mmol})$ in $(33 \%)$ $\mathrm{HBr} / \mathrm{AcOH}(20 \mathrm{~mL})$ was stirred at room temperature until $\mathrm{CO}_{2}$ evolution ceased $(1 \mathrm{~h})$. At this point, distilled water was added carefully to the clear reaction mixture in an ice bath and the resulting solution was washed with chloroform ( $30 \mathrm{~mL}, 3 \times$ ) to remove organic impurities. Solid $\mathrm{NaOH}$ was then added to the aqueous phase up to reach a $\mathrm{pH}$ value of 12 at $0 \stackrel{\circ}{ } \mathrm{C}$ and the resulting solution was saturated with $\mathrm{NaCl}$ and extracted with chloroform $\left(30 \mathrm{~mL}, 3 \times\right.$ ). The organic phase was dried over anhydrous $\mathrm{MgSO}_{4}$ and evaporated under vacuum to obtain a white solid. Yield 81\%; mp 58-61 ${ }^{\circ} \mathrm{C} ;[\alpha]_{D}^{25}=-45.9$ ( $c=0.01, \mathrm{CHCl}_{3}$ ); IR (ATR): 3275, 3099, 2960, 2872, 1644, 1632, $1559 \mathrm{~cm}^{-1} ;{ }^{1} \mathrm{H}$ NMR $(300 \mathrm{MHz}$, $\left.\mathrm{CDCl}_{3}\right) 87.50(\mathrm{~s}, 2 \mathrm{H}), 3.34(\mathrm{~d}, 4 \mathrm{H}, J=5.7 \mathrm{~Hz}), 3.20(\mathrm{~d}, 2 \mathrm{H}, J=3.6 \mathrm{~Hz}), 2.76(\mathrm{t}, 4 \mathrm{H}, J=5.7 \mathrm{~Hz}), 2.30$ $-2.19(\mathrm{~m}, 2 \mathrm{H}), 1.52(\mathrm{~s}, 3 \mathrm{H}), 0.96(\mathrm{~d}, 6 \mathrm{H}, J=6.9 \mathrm{~Hz}), 0.82(\mathrm{~d}, 6 \mathrm{H}, J=6.8 \mathrm{~Hz}) \mathrm{ppm} ;{ }^{13} \mathrm{C}$ NMR $(75$ $\mathrm{MHz}_{\mathrm{CDCl}}$ ) $\delta 174.7,77.5,77.0,76.6,60.4,48.7,38.8,31.0,19.7,16.2$ ppm; HRMS (ESI-TOF) ${ }^{+}$ Calcd. for $\mathrm{C}_{14} \mathrm{H}_{31} \mathrm{~N}_{5} \mathrm{O}_{2}\left(\mathrm{M}+\mathrm{H}^{+}\right)$302.2556. found 302.2563; Anal. Calcd. for $\mathrm{C}_{14} \mathrm{H}_{31} \mathrm{~N}_{5} \mathrm{O}_{2}: \mathrm{C}, 55.8 ; \mathrm{H}$, $10.4 ; \mathrm{N}, 23.2$. found: $\mathrm{C}, 56.0 ; \mathrm{H}, 10.5 ; \mathrm{N}, 23.5$.

Synthesis of 8: Yield 67\%; $\mathrm{mp} 119-115^{\circ} \mathrm{C} ;[\alpha]_{D}^{25}=-16.2\left(c=0.01, \mathrm{CHCl}_{3}\right)$;IR (ATR): 3292, 2956, 2871, 2366, 1689, 1645, 1533, $1467 \mathrm{~cm}^{-1}$; ${ }^{1} \mathrm{H}$ NMR (300 MHz, CDCl $) \delta 7.66$ (s, 3H), $3.31(\mathrm{~s}, 6 \mathrm{H})$, $3.21(\mathrm{~s}, 3 \mathrm{H}), 2.61(\mathrm{~s}, 6 \mathrm{H}), 2.23(\mathrm{~s}, 3 \mathrm{H}), 0.91(\mathrm{~d}, J=41.2 \mathrm{~Hz}, 18 \mathrm{H}) \mathrm{ppm} ;{ }^{13} \mathrm{C} \mathrm{NMR}\left(75 \mathrm{MHz}, \mathrm{CDCl}_{3}\right)$ $\delta 175.0,60.5,54.5,37.5,31.1,19.7,16.4$ ppm; HRMS (ESI-TOF) ${ }^{+}$Calcd. for $\mathrm{C}_{21} \mathrm{H}_{45} \mathrm{~N}_{7} \mathrm{O}_{3}\left(\mathrm{M}^{+} \mathrm{H}^{+}\right)$ 444.3662. found 444.3664; Anal. Calcd. for $\mathrm{C}_{21} \mathrm{H}_{45} \mathrm{~N}_{7} \mathrm{O}_{3}: \mathrm{C}, 56.9 ; \mathrm{H}, 10.2 ; \mathrm{N}, 22.10$. found: $\mathrm{C}$, $56.9 ; \mathrm{H}, 9.9 ; \mathrm{N}, 21.7$.

Synthesis of 5a: The corresponding pseudopeptidic bis(amido amine) precursor 4a (298.4 mg, $0.99 \mathrm{mmol}$ ) was dissolved in $10 \mathrm{~mL}$ of $\mathrm{CHCl}_{3}$ and the solution was placed inside a flask under nitrogen atmosphere. Then, 4-decycloxybenzaldehyde ( $563.2 \mu \mathrm{L}, 535.0 \mathrm{mg}, 2.039 \mathrm{mmol})$ was dissolved in $5 \mathrm{~mL}$ of $\mathrm{CHCl}_{3}$, this solution was added over the solution of the diamine and afterwards, $5 \mathrm{~mL}$ of $\mathrm{CHCl}_{3}$ were added until a final volume of $20 \mathrm{~mL}(0.05 \mathrm{M}$ final concentration each). The mixture was stirred overnight, then a large excess of $\mathrm{Py}^{\mathrm{B}} \mathrm{BH}_{3}(1046 \mu \mathrm{L}, 962.3 \mathrm{mg}$, $10.41 \mathrm{mmol}$ ) was carefully added at $35{ }^{\circ} \mathrm{C}$, and the mixture was allowed to react for $24 \mathrm{~h}$ before being hydrolyzed (conc. $\mathrm{HCl}$, to acidity) and evaporated to dryness. The residue obtained was dissolved in water, basified with $1 \mathrm{~N} \mathrm{NaOH}$, and extracted with $\mathrm{CHCl}_{3}$. The combined organic layers were dried $\left(\mathrm{MgSO}_{4}\right)$ and evaporated in vacuum. The product was purified by flash chromatography on silica gel using $\mathrm{CH}_{2} \mathrm{Cl}_{2}$ as eluent, increasing slowly the polarity with $\mathrm{MeOH}$ and several drops of aqueous ammonia. Yield $68 \% ; \mathrm{mp} 78-81{ }^{\circ} \mathrm{C} ;[\alpha]_{D}^{25}=-$ 32.4 ( $c=0.01, \mathrm{CHCl}_{3}$ ); IR (ATR): 3314, 2955, 2920, 2869, 2851, 1640, 1622, 1613, 1546, 1510 $\mathrm{cm}^{-1} ;{ }^{1} \mathrm{H}$ NMR $\left(500 \mathrm{MHz}, \mathrm{CDCl}_{3}\right) \delta 7.52(\mathrm{t}, J=5.6 \mathrm{~Hz}, 2 \mathrm{H}), 7.18(\mathrm{~d}, J=8.6 \mathrm{~Hz}, 4 \mathrm{H}), 6.84(\mathrm{~d}, J=8.6$ $\mathrm{Hz}, 4 \mathrm{H}), 3.92(\mathrm{t}, J=6.6 \mathrm{~Hz}, 4 \mathrm{H}), 3.68(\mathrm{~d}, J=12.9 \mathrm{~Hz}, 2 \mathrm{H}), 3.54(\mathrm{~d}, J=12.9 \mathrm{~Hz}, 2 \mathrm{H}), 3.38(\mathrm{dd}, J=$ $5.9,11.9 \mathrm{~Hz}, 4 \mathrm{H}), 2.94(\mathrm{~d}, J=4.6 \mathrm{~Hz}, 2 \mathrm{H}), 2.79(\mathrm{t}, J=6.0 \mathrm{~Hz}, 4 \mathrm{H}), 2.08(\mathrm{dtd}, J=4.8,6.9,13.8 \mathrm{~Hz}$, 
2H), $1.76(\mathrm{~m}, 4 \mathrm{H}), 1.44(\mathrm{~m}, 4 \mathrm{H}), 1.27(\mathrm{~m}, 24 \mathrm{H}), 0.94(\mathrm{~d}, J=6.9 \mathrm{~Hz}, 6 \mathrm{H}), 0.86(\mathrm{~m}, 12 \mathrm{H}) \mathrm{ppm} ;{ }^{13} \mathrm{C}$ NMR $\left(125 \mathrm{MHz}, \mathrm{CDCl}_{3}\right) \delta 174.0,158.4,131.7,129.4,114.5,68.2,67.8,52.9,48.9,38.7,31.9$, 31.4, 29.5, 29.5, 29.4, 29.3, 29.3, 26.0, 22.6, 19.6, 17.7, 14.1 ppm; HRMS (ESI-TOF) ${ }^{+}$Calcd. for $\mathrm{C}_{48} \mathrm{H}_{83} \mathrm{~N}_{5} \mathrm{O}_{4}\left(\mathrm{M}+\mathrm{H}^{+}\right)=794.6523$; found: 794.6530; Anal. Calcd. for $\mathrm{C}_{48} \mathrm{H}_{83} \mathrm{~N}_{5} \mathrm{O}_{4}: \mathrm{C}, 72.6 ; \mathrm{H}, 10.5$; $\mathrm{N}, 8.8$; found: $\mathrm{C}, 72.5 ; \mathrm{H}, 10.7 ; \mathrm{N}, 8.9$.

Synthesis of 5b: Yield 59\%; mp 81-84 ${ }^{\circ} \mathrm{C} ;[\alpha]_{D}^{25}=-37.2\left(c=0.01, \mathrm{CHCl}_{3}\right)$; IR (ATR): 3309, 3024, 2920, 2851, 2781, 1610, $1510 \mathrm{~cm}^{-1} ;{ }^{1} \mathrm{H}$ NMR $\left(500 \mathrm{MHz}, \mathrm{CDCl}_{3}\right) \delta 7.49$ (s, 2H), 7.19 (dd, J = 15.0, $8.5 \mathrm{~Hz}, 6 \mathrm{H}), 7.06(\mathrm{~d}, J=8.1 \mathrm{~Hz}, 4 \mathrm{H}), 6.91(\mathrm{~d}, J=8.6 \mathrm{~Hz}, 4 \mathrm{H}), 6.70(\mathrm{~d}, J=8.6 \mathrm{~Hz}, 4 \mathrm{H}), 3.84(\mathrm{t}, J=$ $6.6 \mathrm{~Hz}, 4 \mathrm{H}), 3.55(\mathrm{~d}, J=13.1 \mathrm{~Hz}, 2 \mathrm{H}), 3.40(\mathrm{~d}, J=13.1 \mathrm{~Hz}, 2 \mathrm{H}), 3.31(\mathrm{~d}, J=4.7 \mathrm{~Hz}, 2 \mathrm{H}), 3.28(\mathrm{~m}$, $4 \mathrm{H}), 3.10(\mathrm{~d}, J=18.2 \mathrm{~Hz}, 2 \mathrm{H}), 2.67(\mathrm{~m}, 6 \mathrm{H}), 1.67(\mathrm{~s}, 4 \mathrm{H}), 1.35(\mathrm{~s}, 4 \mathrm{H}), 1.21(\mathrm{~s}, 24 \mathrm{H}), 0.82(\mathrm{t}, J=$ $6.9 \mathrm{~Hz}, 6 \mathrm{H}) ;{ }^{13} \mathrm{C}$ NMR $\left(125 \mathrm{MHz}, \mathrm{CDCl}_{3}\right) \delta 174.1,158.4,137.5,131.1,129.1,128.7,126.8,114.5$, $68.1,63.0,52.1,48.6,39.2,38.6,31.9,29.6,29.5,29.4,29.3,29.3,26.0,22.6,14.1$ ppm; HRMS (ESI-TOF) ${ }^{+}$Calcd. for $\mathrm{C}_{56} \mathrm{H}_{83} \mathrm{~N}_{5} \mathrm{O}_{4}\left(\mathrm{M}+\mathrm{H}^{+}\right)=890.6523$; found: 890.6531; Anal. Calcd. for $\mathrm{C}_{56} \mathrm{H}_{83} \mathrm{~N}_{5} \mathrm{O}_{4}: \mathrm{C}, 75.6 ; \mathrm{H}, 9.4 ; \mathrm{N}, 7.9$; found: $\mathrm{C}, 75.7 ; \mathrm{H}, 9.3 ; \mathrm{N}, 8.0$.

Synthesis of 5c: Yield $35 \%$; $\mathrm{mp} 63-66^{\circ} \mathrm{C},[\alpha]_{D}^{25}=-22.3\left(c=0.01, \mathrm{CHCl}_{3}\right) ;$ IR (ATR): 3324, 2952, 2917, 2850, 2867 1627, 1613, 1581, 1547, $1511 \mathrm{~cm}^{-1}$; ${ }^{1} \mathrm{H}$ NMR $\left(500 \mathrm{MHz}, \mathrm{CDCl}_{3}\right) \delta 7.48(\mathrm{t}, J=$ $5.6 \mathrm{~Hz}, 2 \mathrm{H}), 7.11(\mathrm{~d}, J=8.5 \mathrm{~Hz}, 4 \mathrm{H}), 6.77(\mathrm{~d}, J=8.5 \mathrm{~Hz}, 4 \mathrm{H}), 3.85(\mathrm{t}, J=6.6 \mathrm{~Hz}, 4 \mathrm{H}), 3.61(\mathrm{~d}, J=$ $12.9 \mathrm{~Hz}, 2 \mathrm{H}$ ), $3.48(\mathrm{~d}, J=12.9 \mathrm{~Hz}, 2 \mathrm{H}), 3.30(\mathrm{~m}, 4 \mathrm{H}), 3.07(\mathrm{dd}, J=9.2,4.5 \mathrm{~Hz}, 2 \mathrm{H}), 2.71(\mathrm{t}, J=6.0$ $\mathrm{Hz}, 4 \mathrm{H}), 1.69(\mathrm{~m}, 6 \mathrm{H}), 1.55(\mathrm{~m}, 2 \mathrm{H}), 1.49(\mathrm{ddd}, J=13.4,8.8,4.5 \mathrm{~Hz}, 2 \mathrm{H}), 1.37(\mathrm{~m}, 4 \mathrm{H}), 1.23(\mathrm{~m}$, $24 \mathrm{H}), 0.82$ (dd, $J=15.3,6.8 \mathrm{~Hz}, 12 \mathrm{H}), 0.76(\mathrm{~d}, J=6.4 \mathrm{~Hz}, 6 \mathrm{H}) \mathrm{ppm} ;{ }^{13} \mathrm{C} \mathrm{NMR}\left(126 \mathrm{MHz}, \mathrm{CDCl}_{3}\right) \delta$ 175.3, 158.5, 131.5, 129.3, 114.6, 77.2, 77.0, 76.7, 68.1, 60.9, 52.4, 48.8, 43.0, 38.7, 31.9, 29.4 (m), 26.0, 25.1, 23.2, 22.7, 21.7, 14.1 ppm; HRMS (ESI-TOF) ${ }^{+}$Calcd. for $\mathrm{C}_{50} \mathrm{H}_{87} \mathrm{~N}_{5} \mathrm{O}_{4}\left(\mathrm{M}+\mathrm{H}^{+}\right)=$ 822.6837; found: 822.6838; Anal. Calcd. for $\mathrm{C}_{50} \mathrm{H}_{87} \mathrm{~N}_{5} \mathrm{O}_{4}: \mathrm{C}, 73.0 ; \mathrm{H}, 10.7 ; \mathrm{N}, 8.5$; found: C, 72.7; $\mathrm{H}, 10.3 ; \mathrm{N}, 8.8$.

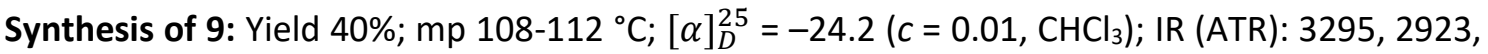
2856, 1690, 1642, $1537 \mathrm{~cm}^{-1}$; ${ }^{1} \mathrm{H}$ NMR $\left(500 \mathrm{MHz}, \mathrm{CDCl}_{3}\right) \delta 7.39(\mathrm{~s}, 3 \mathrm{H}), 7.10(\mathrm{~d}, J=8.5 \mathrm{~Hz}, 6 \mathrm{H})$, $6.76(\mathrm{~d}, J=8.4 \mathrm{~Hz}, 6 \mathrm{H}), 3.84(\mathrm{t}, J=6.6 \mathrm{~Hz}, 6 \mathrm{H}), 3.61(\mathrm{~d}, J=12.9 \mathrm{~Hz}, 3 \mathrm{H}), 3.43(\mathrm{~d}, J=12.9 \mathrm{~Hz}, 3 \mathrm{H})$, $3.29(\mathrm{dt}, J=22.0,6.9 \mathrm{~Hz}, 6 \mathrm{H}), 2.86(\mathrm{~d}, J=4.8 \mathrm{~Hz}, 3 \mathrm{H}), 2.58(\mathrm{t}, J=6.6 \mathrm{~Hz}, 6 \mathrm{H}), 1.97(\mathrm{td}, J=13.7$, $6.9 \mathrm{~Hz}, 3 \mathrm{H}), 1.68(\mathrm{~m}, 6 \mathrm{H}), 1.36(\mathrm{dd}, J=15.1,7.3 \mathrm{~Hz}, 6 \mathrm{H}), 1.23(\mathrm{~m}, 36 \mathrm{H}), 0.84(\mathrm{~d}, J=6.9 \mathrm{~Hz}, 9 \mathrm{H})$, 0.80 (dd, $J=13.2,6.6 \mathrm{~Hz}, 18 \mathrm{H}) ;{ }^{13} \mathrm{C}$ NMR $\left(125 \mathrm{MHz}, \mathrm{CDCl}_{3}\right) \delta 174.0,158.4,131.6,129.2,114.5$, 68.1, 67.7, 54.1, 52.8, 37.1, 31.9, 31.3, 29.6, 29.6, 29.4, 29.3, 29.3 26.1, 22.7, 19.6, 18.0, 14.1 ppm; HRMS (ESI-TOF) ${ }^{+}$Calcd. for $\mathrm{C}_{72} \mathrm{H}_{123} \mathrm{~N}_{7} \mathrm{O}_{6}\left(\mathrm{M}+\mathrm{H}^{+}\right)=1182.9613$; found: 1182.9619; Anal. Calcd. for $\mathrm{C}_{72} \mathrm{H}_{123} \mathrm{~N}_{7} \mathrm{O}_{6}$ : C, 73.1; $\mathrm{H}, 10.5 ; \mathrm{N}, 8.3$; found: $\mathrm{C}, 73.2 ; \mathrm{H}, 10.1 ; \mathrm{N}, 8.1$.

\section{Results and discussion.}

\subsection{Preparation of the second-generation GAPs.}

The design of the new GAPs was based on the introduction of a more flexible and protonable spacer in the middle of the molecules, namely the bis(2-aminoethyl)amine (1) framework. Interestingly, the acylation of this diamine in the conventional conditions for solution phase peptide synthesis selectively rendered the bis(amides) 3a-ccorresponding to the reaction through the two terminal primary amine without the need of previous protection of the internal secondary amine (Scheme 1A). This led to the preparation of the GAPs 5a-c derived from Val, Phe and Leu in good yields after a three-steps (peptide coupling, deprotection of the 
amino groups and reductive amination, Scheme $1 \mathrm{~A}$ ) procedure following a modification of our previous methodology.[55] As an additional structural variation and encouraged by the success in the bipodal GAPs synthesis, a tripodal Val derivative 9 was also prepared starting from tris(2aminoethyl)amine (TREN, compound 6, Scheme 1B). All these compounds were conveniently characterized by spectroscopic and analytical techniques, as detailed in the corresponding electronic supporting information.
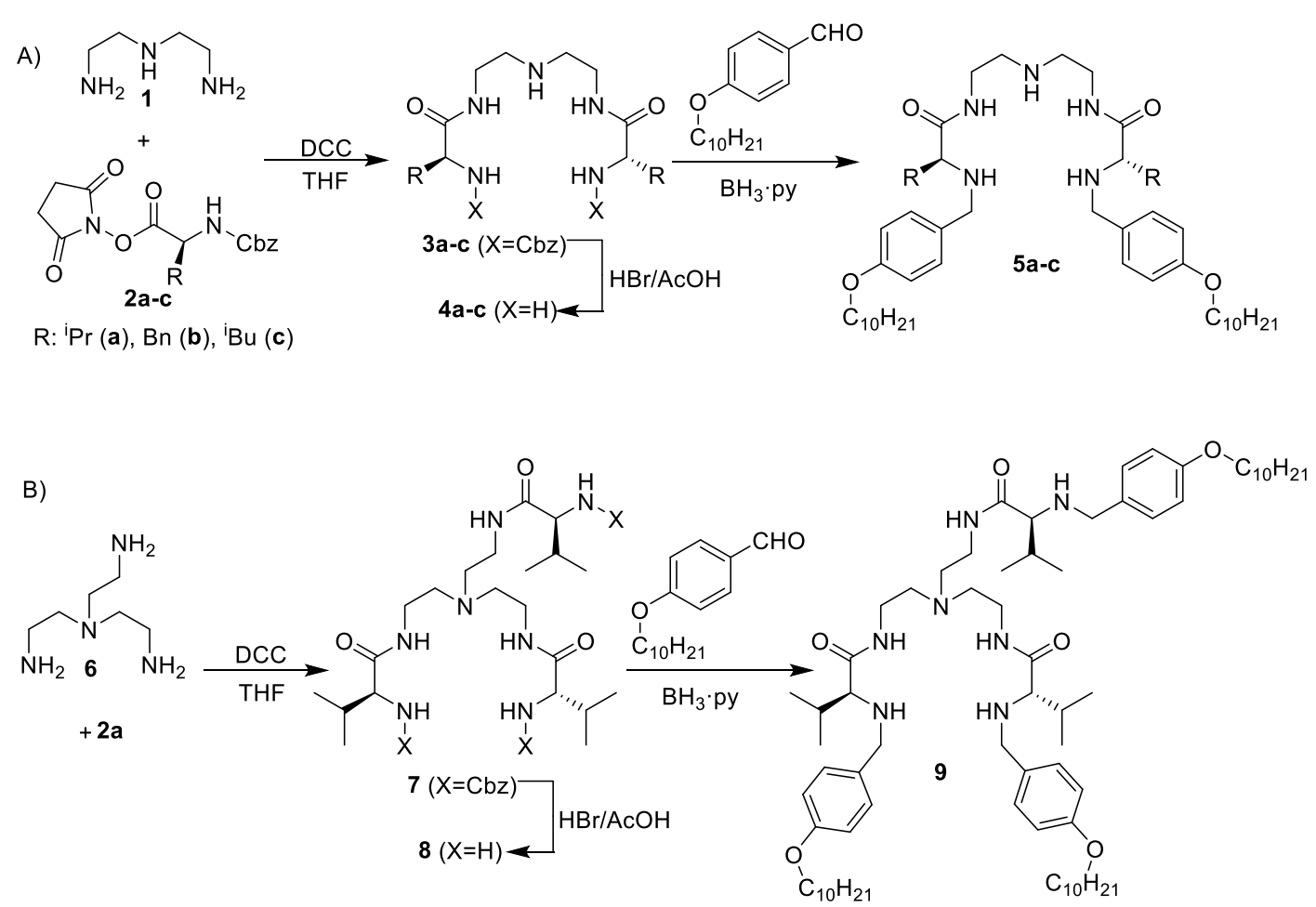

Scheme 1. Synthesis of GAPs 5a-c (A) and 9 (B)

\subsection{Formation of ultrastructures by non-covalent self-assembly.}

Scanning Electron Microscopy (SEM) experiments were carried out to analyze the selfassembly behavior of the different Gemini amphiphiles and the solid-state supramolecular assemblies formed under different environmental conditions. Since the considered GAPs are amphiphilic, the samples for the SEM studies were prepared from a variety of solutions involving several solvents and polarities such as $\mathrm{CHCl}_{3}, \mathrm{CHCl}_{3}+\mathrm{MeOH}$ (1:1), $\mathrm{MeOH}$ or $\mathrm{MeOH}+\mathrm{H}_{2} \mathrm{O}(1: 1)$. Besides, samples from $\mathrm{MeOH}+\mathrm{H}_{2} \mathrm{O}(1: 1)$ at acidic and at basic $\mathrm{pH}$ values were also considered. The objective was to analyze in detail the influence of the specific media used in the nano-structure of the aggregates formed.[35-41] As a general trend, the self-assembly revealed to be more effective for samples grown from polar solvents, as in this case the formation of different nano-structures such as fibers, vesicles and flower-like assemblies could 
be observed (Figure 2). In contrast, the SEM analysis for samples prepared from chloroform solutions showed amorphous materials for all pseudopeptidic compounds. Such lack of selfassembled nanostructures can be attributed to the prevalence of strong intra-molecular hydrogen bonding and to the good solvation of the hydrophobic tail in the chloroform solvent.[40] Studies performed with samples obtained from polar media $\left(\mathrm{MeOH}, \mathrm{MeOH}+\mathrm{H}_{2} \mathrm{O}\right)$ showed how some of these amphiphiles were able to self-assemble toward the formation of fibers with different sizes and widths. The size of these fibers was in the range of 100-300 nm in width, but their grouping in bunches of several micrometers could also be observed. Among all compounds measured in $\mathrm{MeOH}$ and $\mathrm{MeOH}+\mathrm{H}_{2} \mathrm{O}$ under neutral conditions, only $\mathbf{5 c}$ was unable to form fibers from both media. Thus, the presence of the Leu side chain seems to have an important effect on the final self-assembly properties as has been observed in other instances.[35] In this regard, it is important to bear in mind that changing from Val to Leu involves that the ramification in the side chain moves from the $\beta$-position to the $\gamma$-position of the amino acid. As for related systems, the formation of fibers is attributed to the involvement of the GAPS in the formation of intermolecular hydrogen bonds with solvent molecules, leading to the unfolding of the amphiphiles and the prevalence of more flexible extended conformations, which favor the assembly into fibrillar structures (see below). The effect of the $\mathrm{pH}$ on this self-assembly was also tested by comparing the results obtained in $\mathrm{MeOH}+\mathrm{H}_{2} \mathrm{O}(1: 1)$ under neutral, basic and acidic conditions. When changing from neutral to basic media, no big changes were detected, with fibers being observed for the three $C_{2}$ GAPs, including $\mathbf{5 c}$, while the $C_{3}$ GAP 9 self-assembled into a flower-like morphology (Figure 2, right column). The different morphology in the assembly of 9 could be rationalized by considering that the presence of a third arm in the GAP structure allows growing the corresponding fibers in different directions increasing their dimensionality and thus finally leading to non-parallel bunches of fibers as shown in Figure 2. 

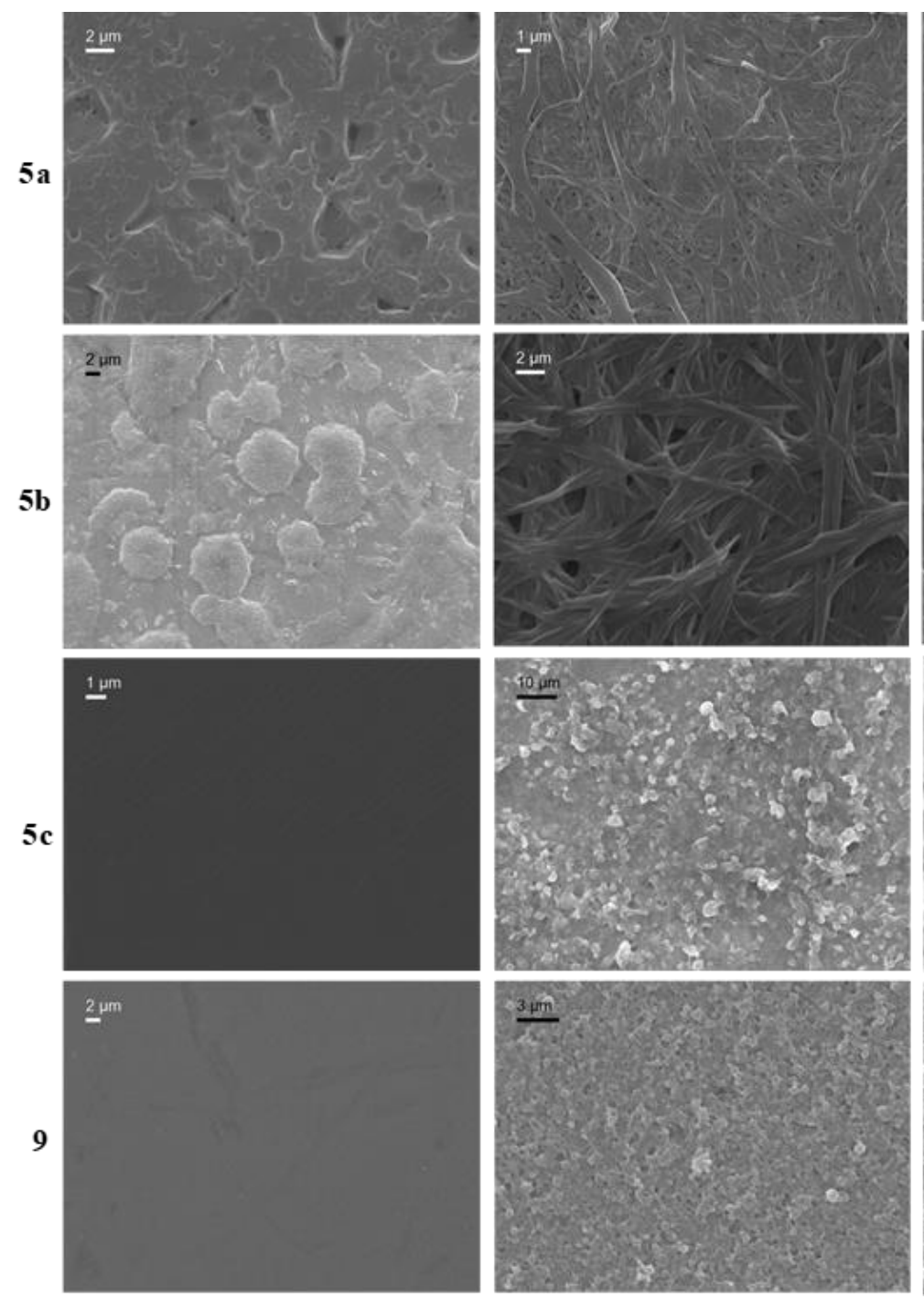
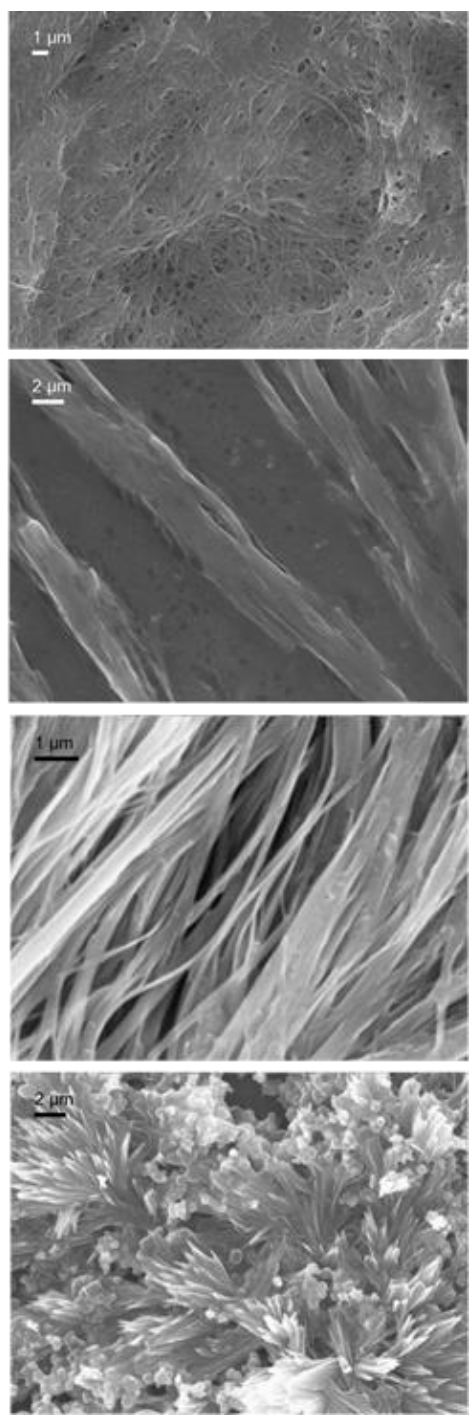

Figure 2. Selected SEM micrographs of $\mathbf{5 a}, \mathbf{5 b}, \mathbf{5} \mathbf{c}$, and $\mathbf{9}$ grown from $\mathrm{CHCl}_{3}$ (left), $1: 1 \mathrm{MeOH}$ : $\mathrm{H}_{2} \mathrm{O}$ (middle) and $1: 1 \mathrm{MeOH}: \mathrm{H}_{2} \mathrm{O}+\mathrm{NaOH}$ (right). Scale bars are presented at each picture.

In an acidic medium, however, a very different behavior was obtained. The fiber-like assemblies previously observed were not present in any case, and for all studied samples the formation of micrometric size spheres was observed. Such spheres ranged in size from $0.3 \mu \mathrm{m}$ to $3 \mu \mathrm{m}$. The formation of microspheres in related systems has been attributed to the combination of hydrophobic interactions and electrostatic repulsions in the charged polar heads, which play a major role in the formation of vesicles from GAPs (Figure 3, left). [38,39] In addition, the formation of spherical microstructures from acidic aqueous methanolic media was also investigated for all GAPs by using complementary techniques such as Transmission Electron Microscopy (TEM) and Atomic Force Microscopy (AFM).A self-assembly into vesicles could be observed for all new synthetic GAPs from the micrographs by the two techniques. 
However, the pictures presented in Figure 3 display the presence of vesicles with slightly different sizes. In general, the vesicles observed for all GAPs in TEM are smaller than those seen in AFM and SEM micrographs. The GAPs behave similarly in this regard. Most likely, the differences in sample preparation for each technique, including the nature of the surface of the support (alumina for SEM, carbon for TEM and mica for AFM) and in experimental conditions can have some effects on the self-assembling.

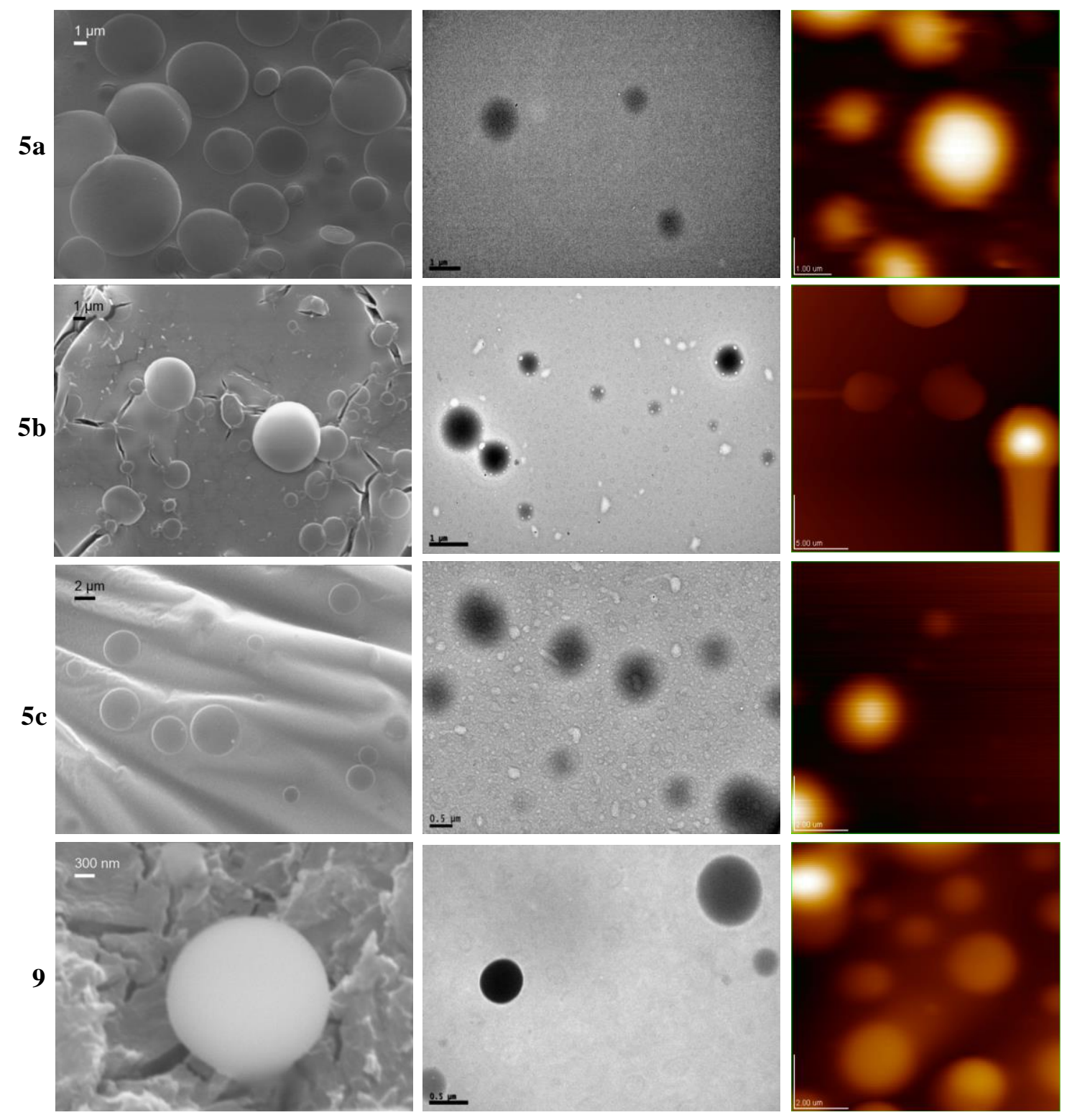

Figure 3 Selected SEM (left), TEM (middle) and AFM (right) micrographs of $\mathbf{5 a}, \mathbf{5 b}, \mathbf{5} \mathbf{c}$ and $\mathbf{9}$ grown from $1: 1 \mathrm{MeOH}: \mathrm{H}_{2} \mathrm{O}+\mathrm{HCl}$.

\subsection{Structural characterization of the GAPs in solution.}

Regarding the corresponding solution structures, some interesting trends were observed when analyzing the molecules by NMR spectroscopy under different experimental conditions. Thus, 
several ${ }^{1} \mathrm{H}$ NMR experiments were initially carried out for the Val derived GAP 5 ab in both nonpolar $\left(\mathrm{CDCl}_{3}\right)$ and polar $\left(\mathrm{CD}_{3} \mathrm{OD}\right)$ solvents, and in an acidic medium $\left(\mathrm{CD}_{3} \mathrm{OD}+\mathrm{DCl}\right)$. Besides, two different concentrations ( $1 \mathrm{mM}$ and $20 \mathrm{mM}$ ) were studied in all cases. First of all, when the concentration of the GAPs was increased 20 times in both solvents, only negligible changes were observed in the corresponding ${ }^{1} \mathrm{H}$ NMR spectra. This suggests that, for the range of concentrations analyzed, the level of aggregation can be considered negligible. On the contrary, the ${ }^{1} \mathrm{H}$ NMR spectra obtained displayed very different features as a function of solvent polarity or medium acidity (Figure 4). The high value of the chemical shift (>7.00 ppm) of the amide $\mathrm{NH}$ signal in $\mathrm{CDCl}_{3}$ is indicative of the involvement of these amide groups as hydrogen bond donors in H-bonds. The chemical shift of the NH signal practically does not change with the concentration (1-20 $\mathrm{mM}$ in $\mathrm{CDCl}_{3}$ ) suggesting that the $\mathrm{H}$-bonds implicating the amide NH groups must be intramolecular. The signals for the $\alpha$ and $\beta$ protons of the Val moieties also appear at higher chemical shifts, which is also in line with this proposal (see Figure 4 for the numbering of protons). When the ${ }^{1} \mathrm{H}$ NMR spectrum was acquired in a polar protic solvent like methanol, important changes were observed. Thus, several signals corresponding to the structural elements of the amino acid component $(\alpha, \beta, \gamma)$ or the central aliphatic spacer (A) moved upfield. However, the signals for the hydrogen atoms located in the long aliphatic tails remained essentially constant. These observations agreed with at least a partial disruption of the intramolecular $\mathrm{H}$-bonds responsible of the folded structure in the GAPs, which should favor a transition towards an unfolded linear conformation. The addition of $\mathrm{DCl}$ to the solution of $5 \mathrm{a}$ in $\mathrm{CD}_{3} \mathrm{OD}$ also produced important changes in the observed NMR spectrum. The protonation of the amino nitrogen atoms was accompanied by significant increases in the chemical shifts of the signals for the protons closer these protonation sites (1, $\alpha, \beta$ and $\gamma$ ). Besides, the observed deshielding of the protons at positions 2, 3 (at the aromatic ring) and 4 (at the aliphatic tail) suggested that the anisole substructure slightly increased its polarization upon nitrogen protonation. Moreover, the signals for the protons at the hydrophobic chains showed a small upfield shift (0.010-0.025 ppm). Interestingly, under these acidic conditions, the protons at the positions $A$ and $B$ of the spacer experiment an appreciable downfield shift and increase their anisochrony, in particular at $1 \mathrm{mM}$, which again suggests that the central spacer experiences a restricted mobility when the amino groups of the GAP are protonated, but also that the two sides in this spacer display a different chemical environment in a folded conformational arrangement. The higher chemical shift value observed for the signal(s) of protons B indicates that all the amino groups in the structure, the benzylic ones and the one in the middle of the central spacer are mainly protonated under those conditions. A very different behavior was observed for the signal for protons 1 ( 1 and $\left.1^{\prime}\right)$ 
that were significantly downfield shifted but become equivalents in acidic medium. All of these observations, in particular the large splitting of the signals for the methylene groups $A$ and $B$ and the significant change in the $1 / 1^{\prime}$ signals, agree with the predominant formation of a folded conformation in the acidic environment that is significantly different from the one that could be present in chloroform. In addition, similar trends were observed for the other GAPs derived from different amino acids, suggesting a similar conformational behavior.

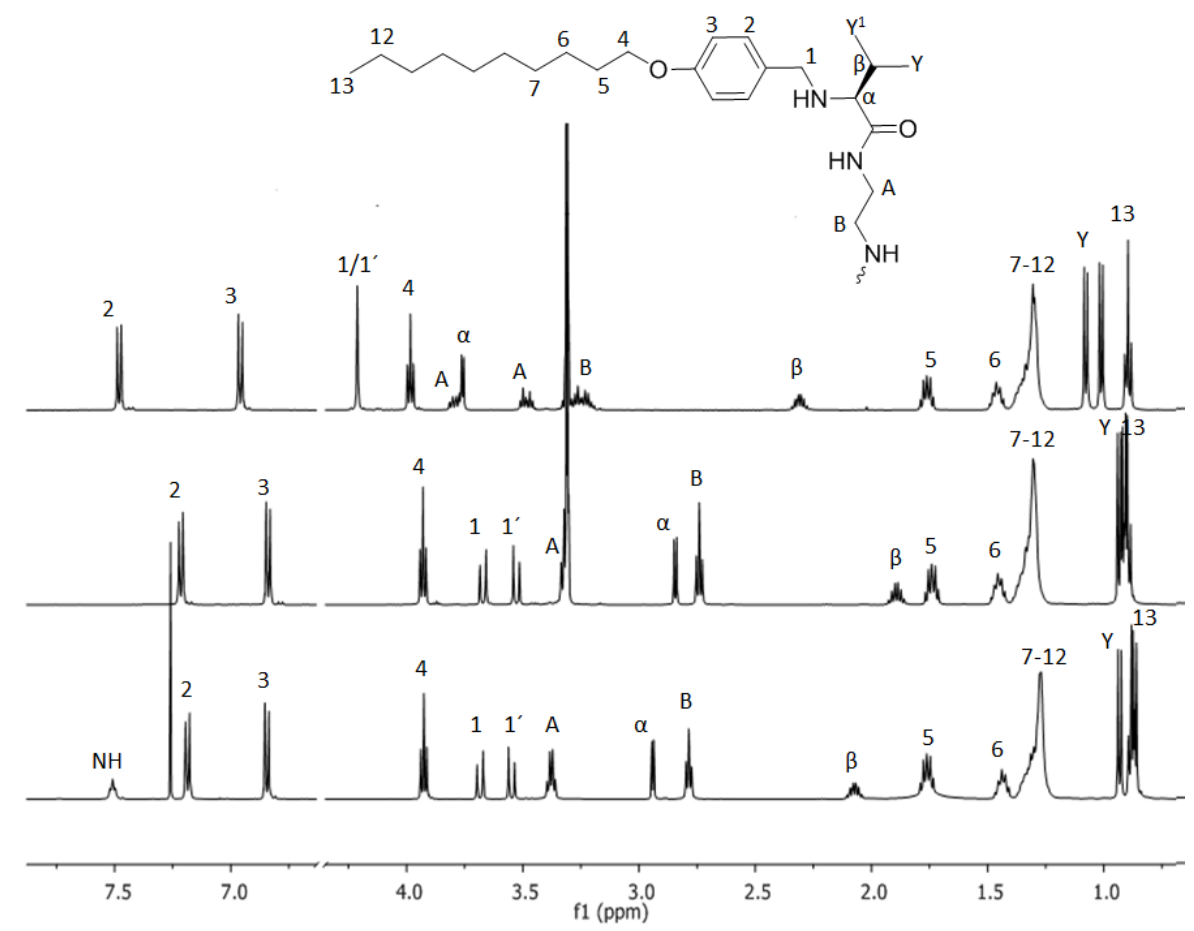

Figure 4. ${ }^{1} \mathrm{H} \mathrm{NMR}\left(500 \mathrm{MHz}, 303 \mathrm{~K}, 20 \mathrm{mM}\right.$ ) spectra for $5 \mathrm{a}$ in $\mathrm{CDCl}_{3}$ (bottom), $\mathrm{CD}_{3} \mathrm{OD}$ (middle) and $\mathrm{CD}_{3} \mathrm{OD}+\mathrm{DCl}$ (top). Assignment of the signals follow the arbitrary lettering of the chemical substructure shown at the top of the figure.

In order to better characterize the conformational change associated to the protonation process, we took advantage of the chirality of the molecules and the presence of two UV chromophores. Thus, electronic absorption (UV) and circular dichroism (CD) spectra were recorded in $\mathrm{MeOH}$ with/without added acid at different concentrations, showing a perfect linearity within 0.012-0.5 mM, which again suggested a negligible aggregation in these conditions. The UV spectra of all GAPs in neutral and acidic $\mathrm{MeOH}$ displayed two characteristic bands corresponding to the aromatic chromophore: the first one and more intense appearing in the region close to $230 \mathrm{~nm}\left(\pi \rightarrow \pi^{*}\right)$ while the less intense second one less intense is observed at ca. $275 \mathrm{~nm}\left(\mathrm{n} \rightarrow \pi^{*}\right.$ ) (see bottom spectra in Figure 5A for 5a). Upon protonation, 
the bands at the UV spectra for all GAPs showed a small red shift of the $\pi-\pi^{*}$ band (from 227 to $232 \mathrm{~nm}$ ) and also a small blue shift of $\mathrm{n}-\pi^{*}$ band (from 277 to $274 \mathrm{~nm}$ ). Moreover, a lower energy and weaker band observed at $330 \mathrm{~nm}$ can be associated to a CT (charge transfer) process (see inset in Figure 5A, bottom). This charge transfer might be associated with the cation- $\pi$ complex formation between the electron rich anisole chromophore and the ammonium cation in a folded conformation.
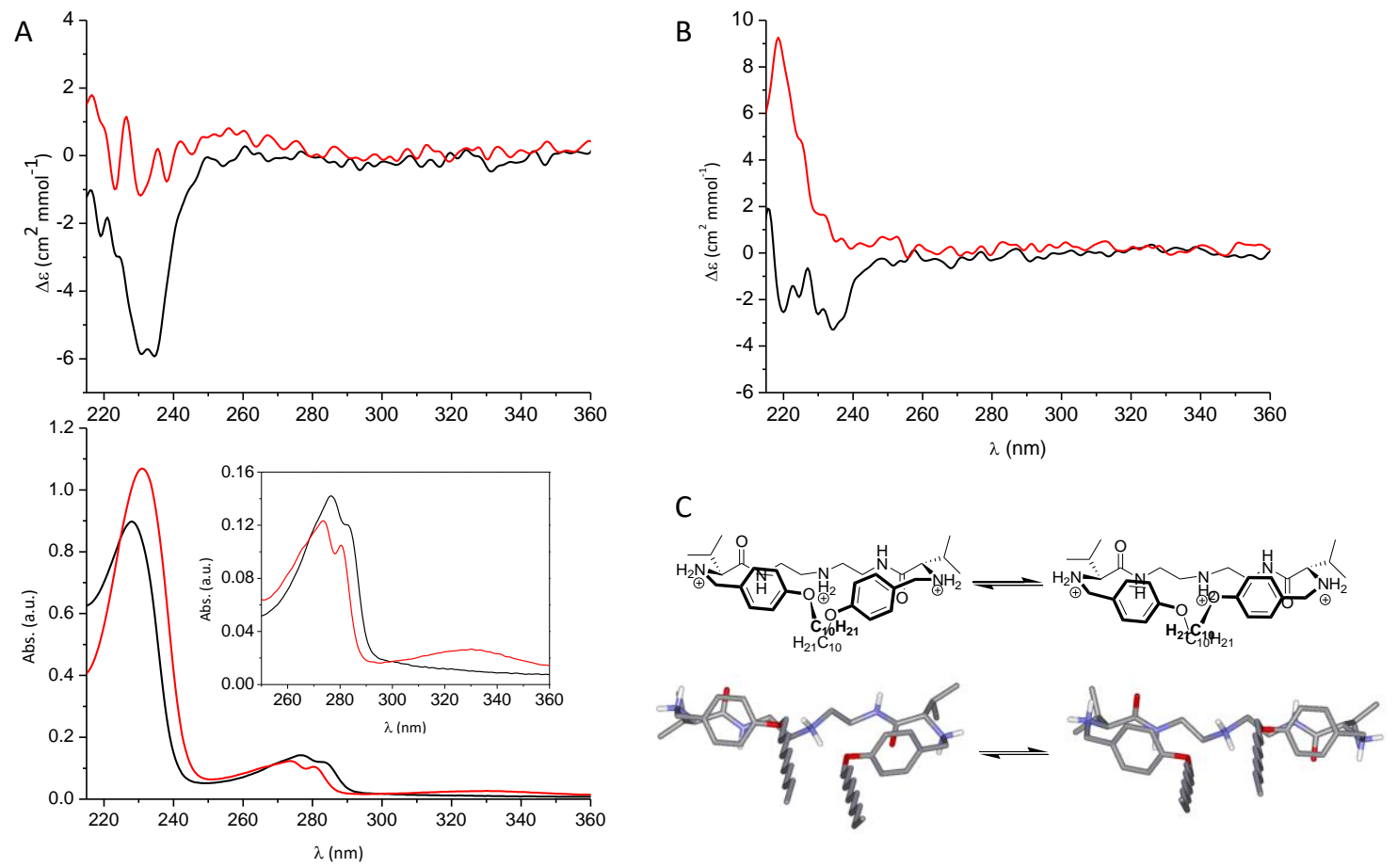

Figure 5. (A) UV (bottom) and CD (top) spectra for 5 a at $0.04 \mathrm{mM}$ concentration in neutral (black) and acidic (red) $\mathrm{MeOH}$. (B) $\mathrm{CD}$ spectra for $\mathbf{5 b}$ at $0.04 \mathrm{mM}$ concentration in neutral (black) and acidic (red) MeOH. (C) Proposed conformation for fully protonated $\mathbf{5 a}$.

Circular Dichroism (CD) spectra also provided an interesting information. When neutral methanol was used, the GAPs presented a negative band at $230 \mathrm{~nm}$ of low intensity, which is attributed to a proper relative orientation of the anisole groups of the hydrophobic tails ( $\pi-$ $\pi^{*}$ transition). Moreover, there are not big differences in the CD intensity of the signals for the GAPs bearing aliphatic amino acid side chains, i.e. valine and leucine $\left(\Delta \varepsilon_{\max }=-6 \mathrm{~cm}^{2} \cdot \mathrm{mmol}^{-1}\right)$, whereas in the case of the GAP containing an aromatic amino acid side chain a smaller effect was observed $\left(\Delta \varepsilon_{\max }=-2.8 \mathrm{~cm}^{2} \cdot \mathrm{mmol}^{-1}\right)$ (Figure $5 \mathrm{~B}$, black line) which suggests an interference of the side chain aromatic rings with the achievement of the proper orientation of the anisole groups. Upon acidification, remarkable changes were observed in the CD spectra, and these 
were very different depending on the exact structure of the GAP (compare top graphs in Figures $5 \mathrm{~A}$ and $5 \mathrm{~B}$ ). In the case of $\mathbf{5 a}$ (Figure $5 \mathrm{~A}$, red line), the $C D$ signal surprisingly almost disappeared upon protonation, that could suggest the formation of folded structures leading to vesicles. Several examples have illustrated how the fibers to vesicles is usually accompanied by a signal reduction in the corresponding CD spectra.[57-59] However, it must be noted that CD measurements, in the experiments considered here, involved concentrations at which no aggregation takes place. Consequently, the loss of the $C D$ signal can involve the coexistence of two similar chromophores but complementary to each other, rendering ultimately a compensation of the corresponding signals on the CD spectra as represented in Figure $5 \mathrm{C}$. In the case of $\mathbf{5 b}$ (Figure B), the original CD signal disappeared upon protonation, and a positive band $\left(\Delta \varepsilon=2.2 \mathrm{~cm}^{2} \cdot \mathrm{mmol}^{-1}\right)$ was observed at shorter wavelengths, probably due to the aromatic side chains. For the tripodal compound 9, the CD spectrum presented a very weak negative signal $\left(\Delta \varepsilon=-2 \mathrm{~cm}^{2} \cdot \mathrm{mmol}^{-1}\right)$, which indicates the presence of a more complex mixture of conformations, including complementary conformers like those mentioned above.

\subsection{Real-time monitoring of the interactions leading to the self-assembly.}

With the aim of studying the process connecting the solution containing the pre-assembled GAPs with their aggregation and the development of the corresponding nanostructures in the solid state, ATR FT-IR spectroscopy experiments were carried out. This kind of experiments allow to analyse the progression of the self-assembly as they provide a detailed analysis of the modifications in the environment of the different functional groups as the aggregation progresses. For this study, 5a was again selected initially as archetypal GAP. An ATR sampling device was used and the sample (20 mM solution) was allowed to slowly evaporate in the sample holder while the corresponding FT-IR spectra were continuously acquired. Thus, the whole process from non-aggregation (as indicated by NMR experiments, no aggregation takes place in a $20 \mathrm{mM}$ solution) to solid state was analysed by following the variations in some key IR bands. Very similar trends were observed for $\mathbf{5 b}$. Selected FT-IR bands for $\mathbf{5 a}$ are shown in Figure 6 , while those for $\mathbf{5 b}$ along with a detailed band assignment Table and a thorough discussion on the spectra can be found in the corresponding section of the supporting information (ESI, Figure S13, Table S1). The most significant changes observed upon concentration (solvent evaporation) affected to the bands corresponding to $\mathrm{N}-\mathrm{H}$ stretching (amide A, 3300-3400 $\mathrm{cm}^{-1}$ ), aliphatic $\mathrm{C}-\mathrm{H}$ stretching $\left(2800-3000 \mathrm{~cm}^{-1}\right), \mathrm{C}=\mathrm{O}$ stretching (amide I, $1600-1700 \mathrm{~cm}^{-1}$ ) and on-plane N-H bending (amide II, 1500-1570 $\left.\mathrm{cm}^{-1}\right) \cdot[35,60-62]$ This is reasonable, assuming the increase of intermolecular interactions mediated by hydrogen bonding that can take place upon concentration. $[63,64]$ In chloroform, both amide A and II 
bands displayed red shifts upon drying along with a clear sharpening (Figure 6A,C), which is consistent with the participation of amide bonds in intermolecular hydrogen bonds upon concentration. At the same time, the bands corresponding to the $\mathrm{CH}$-stretching of the aliphatic tails also shift to lower wavenumbers from 2927 and $2856 \mathrm{~cm}^{-1}$ to 2919 and $2851 \mathrm{~cm}^{-1}$ for $5 \mathrm{a}$, which is indicative of the generation of structures with reduced mobility and in a more symmetric environment, in agreement with the trends observed for the ordering of lipids in membranes.[65-68]

A

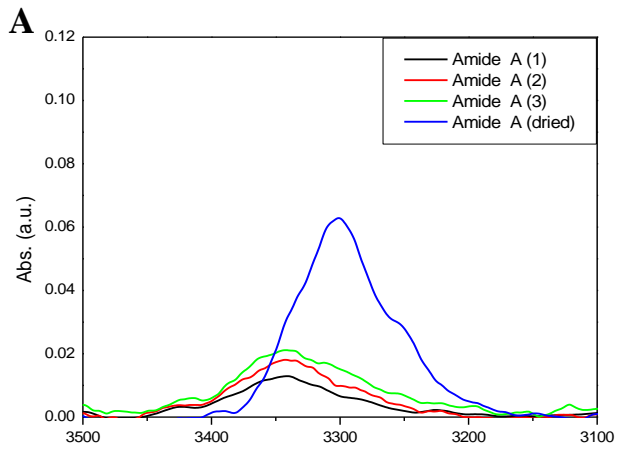

$\mathbf{C}_{0}$
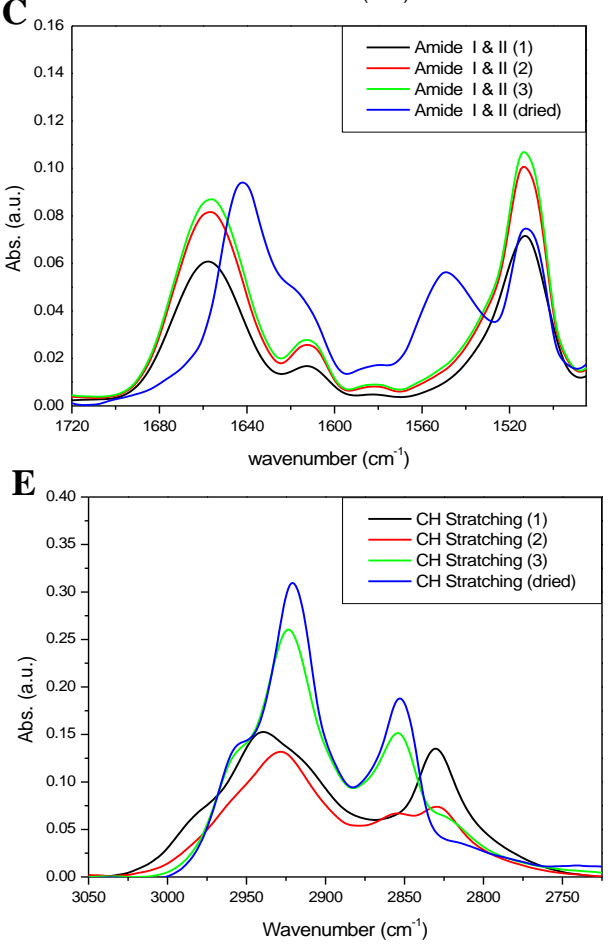

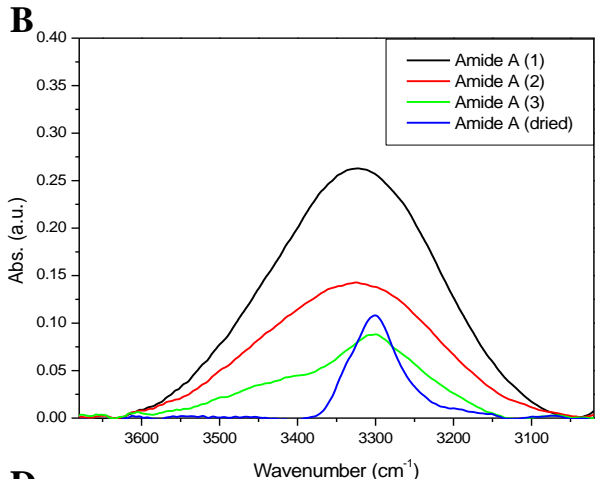

$\mathbf{D}_{025}$
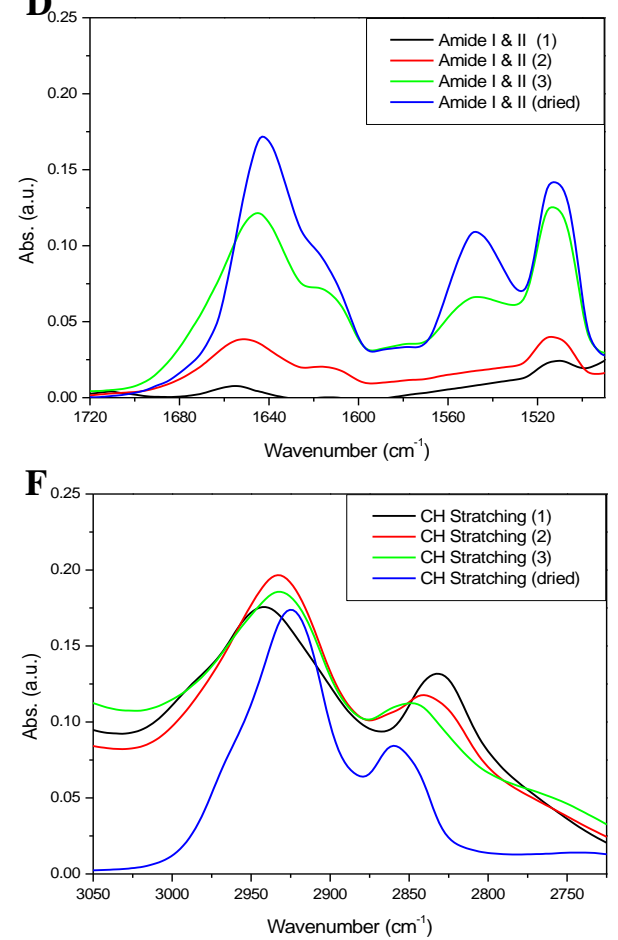

Figure 6. Partial ATR FT-IR spectra of $5 a$ under different conditions: amide $A$ in $\mathrm{CHCl}_{3}(\mathrm{~A})$ and in $\mathrm{MeOH}(\mathrm{B})$; amide I and II in $\mathrm{CHCl}_{3}(\mathrm{C})$ and in $\mathrm{MeOH}(\mathrm{D})$; $\mathrm{CH}$ stretching in $\mathrm{MeOH}(\mathrm{E})$ and in acidic $\mathrm{MeOH}(\mathrm{F})$. 
In general, the solids obtained from chloroform and from $\mathrm{MeOH}$ display very similar vibrational bands in the regions studied and only very minor shifts in the corresponding bands (ESI, Table S1). In methanol, similar trends as in chloroform are detected for the amide A and amide I bands (Figure $6 \mathrm{~B}, \mathrm{D}$ ) although changes are less pronounced, most likely for the strong involvement in hydrogen bonding with the solvent in solution. Some sharpening and a red shift are observed, upon drying, while the expected new band at $1545-1500 \mathrm{~cm}^{-1}$ appeared in the amide II region, suggesting $\mathrm{C}=\mathrm{O} \cdots \mathrm{HN}$ intermolecular $\mathrm{H}$-bonds formation and the presence at the pseudopeptidic moiety of $\beta$-stack conformations.[69] A remarkable difference in solution is observed for the bands corresponding to the $\mathrm{C}-\mathrm{H}$ asymmetric and symmetric stretching, as the shift observed upon drying do not correspond directly to those in chloroform or to the trends that could be elaborated from studies in lipid membranes. Relative to the data in chloroform, the symmetric band is shifted in methanol by $\Delta v=13 \mathrm{~cm}^{-1}$ while the asymmetric one is shifted in the opposite sense with $\Delta v=-26$. This clearly reflects the different solvation of the aliphatic tails in the two solvents and probably indicates a stiffening of these tails in the $\mathrm{MeOH}$ solution. When passing to the solid state, the corresponding bands do not move in the same direction, but showed important red (from 2940 to $2920 \mathrm{~cm}^{-1}$ for 5 a in the case of the symmetric stretching) and blue (from 2830 to $2853 \mathrm{~cm}^{-1}$ for the asymmetric stretching) shifts, indicating that the long aliphatic chains form a liquid crystal-like phase.[70] This suggests that the GAP molecules are pre-associated in $\mathrm{MeOH}$, with an important participation of the hydrophobic regions in this initial stage of aggregation, and that important changes in these hydrophobic interactions can occur upon drying.

In acidic methanol, the presence of the ammonium salt precludes the accurate analysis of the amide $A$ band, while the amide I band appears in solution at $c a .1680 \mathrm{~cm}^{-1}$. This represents an increase of $25 \mathrm{~cm}^{-1}$ compared to the position of the same band before protonation and this can be associated to the presence of ammonium groups in the proximity of the carbonyl groups, which significantly difficult the corresponding stretching vibration. Besides, this band is very broad, suggesting the contribution from carbonyl groups with slightly different environments in the aggregated species.The symmetric and asymmetric $\mathrm{C}-\mathrm{H}$ stretching bands (Figure 6F) were observed at only slightly higher values than in neutral methanol for all the range of concentrations, suggesting again the presence of pre-aggregated species in solution.

The transition between different phases in the solid state was also studied using Differential Scanning Calorimetry that revealed the presence of several phase transitions including glass or solid-to-solid transitions, melting and crystallization processes (ESI, Figure S14). These transitions are accompanied with changes in the interactions between the functional groups as 
revealed by temperature-dependent ATR FT-IR spectroscopy (ESI, Figure S15). A more detailed discussion can be found in the corresponding section of the electronic supporting information.

\subsection{Stimulus-responsive self-assembly of GAPs in aqueous media.}

The full analysis of the structural and ultrastructural data compiled in this study allows to propose a mechanism for the dual behavior of the GAPs upon the action of a simple stimulus such as the $\mathrm{pH}$ variation, similar to the one proposed for the previous first-generation GAPs, but that can be enhanced by the presence of a basic nitrogen atom in the spacer. The flexible and amphiphilic nature of the molecules allows proposing the presence of both extended and folded conformations in solution (Figure 7). The equilibrium between these structures will be modulated by the delicate balance between the GAP-GAP and GAP-solvent non-covalent interactions. Thus, in aqueous methanol at slightly basic $\mathrm{pH}$, the $\mathrm{H}$-bonding interactions with the solvent would favor the extended conformation which, upon drying, facilitate establishing intermolecular hydrogen bonding at the pseudopeptidic moiety and hydrophobic interactions of the tails in a sheet-like stack disposition, leading to fiber-like morphologies. On the other hand, in acidic media, the protonation of the spacer and the pseudopeptidic amino groups would lead to a folded conformation that can self-assemble by hydrophobic interactions in vesicle-like morphologies. These vesicles would have some advantages over the ones formed by the first-generation GAPs, since they would expose to the bulk solvent a much more polar surface (blue cartoon in Figure 7) containing a protonated spacer with a nitrogen in the center.

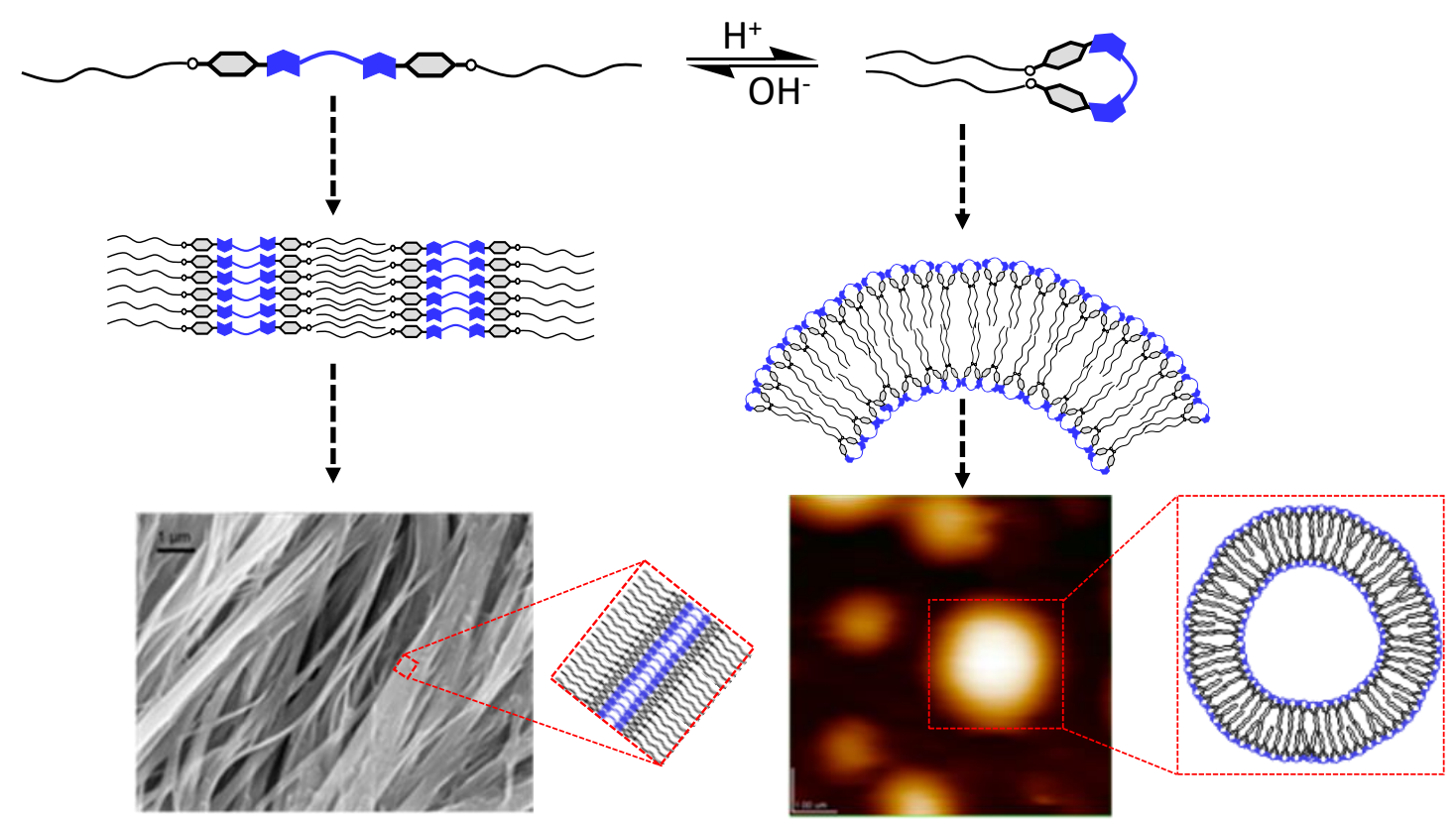

Figure 7. General representation of the dual self-assembly of Gemini pseudopeptides to form either fibers or vesicles. 
Following that model, we hypothesized that these GAPs could form stable self-assemblies in media with larger aqueous contents, which is interesting for biological applications. Thus, we checked that 5a also forms similar microstructures (fibers and vesicles) in water containing only $1 \% \mathrm{EtOH}$ (Figure 8). We used ethanol since this alcohol is biologically friendly and acceptable for pharmaceutical preparations.
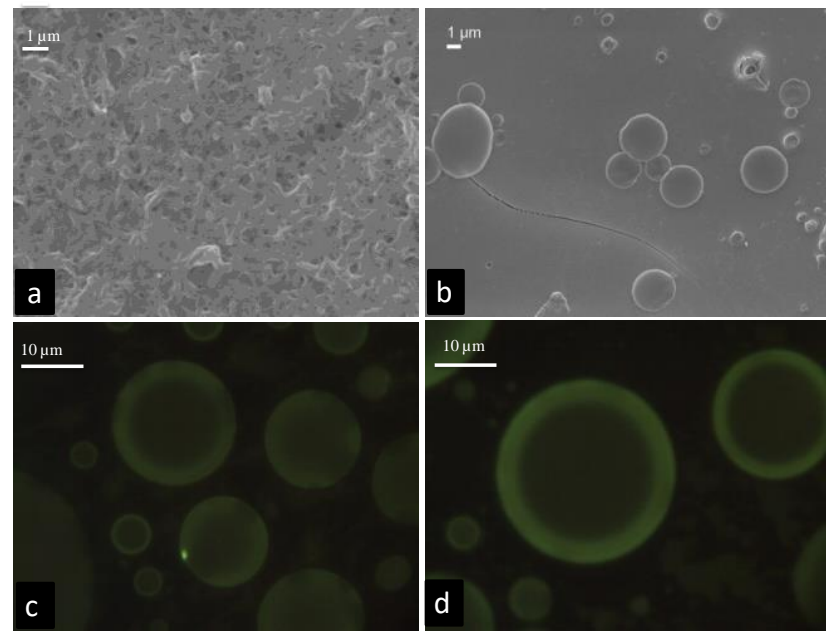

Figure 8. SEM micrographs of 5a grown from $1: 99 \mathrm{EtOH}: \mathrm{H}_{2} \mathrm{O}(\mathrm{A})$ and $1: 99 \mathrm{EtOH}: \mathrm{H}_{2} \mathrm{O}+\mathrm{HCl}$ (B). Scale bars are presented at each picture. (C, D) Fluorescence microscopy images of 5a vesicles in citrate aqueous buffer ( $\mathrm{pH} 6.8)$ loaded with carboxyfluorescein.

Additionally, we measured the corresponding Critical Aggregation Concentration (CAC) of the GAPs in pure water by using pyrene as the fluorescent probe (ESI, Figure S16, Tables S2S5).[71] Different experimental conditions were assayed $(\mathrm{pH}$, ionic strength) and the CAC values obtained for the different GAPs were in the 4-25 $\mu \mathrm{M}$ range. Interestingly, these CAC values were always smaller than those obtained for related GAPs lacking the secondary amino group in the central spacer, in particular for the Phe derivative: $48 \mu \mathrm{M}$ for the Phe-GAP containing a 1,4-diaminobutane spacer vs. $4 \mu \mathrm{M}$ for the one derived from bis(2aminoethyl)amine 5b under similar conditions.[40] Slight differences were observed for the different GAPs and using different aqueous media, such as acetate or citrate buffers at $\mathrm{pH}$ values ranging from 2.2 to 6.8 . Also the presence of salt (up to $1 \mathrm{M} \mathrm{NaCl}$ ) was tolerated with minimal perturbation in the corresponding CAC values. Despite we expected a lower CAC for the tripodal GAP 9, we observed no remarkable differences as compared with the bipodal counterpart 5a. These results suggest that these GAPs could be used as encapsulating agents and delivery systems for biological and pharmaceutical applications under biologically or physiologically relevant conditions. In order to demonstrate that, we prepared vesicles of $\mathbf{5 a}$ $(200 \mu \mathrm{M})$ in pure water (citrate buffer at $\mathrm{pH} 6.8)$ and loaded with sodium fluorescein (50 $\mu \mathrm{M})$. 
The fluorescence microscopy images (Figure $8 c, d$ ) clearly showed the formation of giant vesicles, since the absence of organic co-solvent increases the hydrophobic interactions between GAP molecules. Moreover, the images showed the green fluorescent hydrophobic shells while both the external bulk solution and the inner cavity of the vesicles remained mainly non-fluorescent. This observation confirmed that the formed vesicles are hollow and that the fluorescent probe was incorporated within the hydrophobic layer of the vesicles membrane. These preliminary results suggest the possibility of using these GAPs as artificial delivery systems, where the central nitrogen of the spacer remains exposed to the bulk solution, thus being a perfect point for synthetic elaboration to anchor signaling or recognition molecules.

\section{Conclusions.}

The formation of self-assembling structures from peptide-like amphiphilic molecules is a wellknown process in literature, $[8,10,16,18,21,28-31,50,52]$ that is usually controlled by modifications in the chemical structures $[10,19]$ or upon the action of different stimuli $[20,21,25-27,44,45]$ like $\mathrm{pH}$ or the presence of an organic solvent. To study the process, a combination of experimental techniques is commonly used $[9,10,13,19,20]$ in most cases applied to the final self-assembled structure. However, studies monitoring the whole process from the solution to the aggregate are less common.[9] Here we report on the synthesis of a second-generation of Gemini Amphiphilic Pseudopeptides (GAPs) by specific variations in the central diamino spacer, introducing an additional basic secondary amine group and leading to a family of molecules that self-assemble displaying a variety of microstructures as a function of the polarity and acidity of the solvent. The presence of the additional functionalities in the spaces was expected to modify the intrinsic self-assembly properties of the new GAPs as well as their response under a variety of external stimuli, in particular $\mathrm{pH}$ changes. A thorough structural and morphological analysis of the self-assembly process from the non-aggregated solution (NMR, UV, CD) to the solid aggregates (SEM, TEM, AFM, DSC, ATR FT-IR), in addition to the monitoring of the process (ATR FT-IR) allowed proposing a reasonable mechanism for the self-assembly.[40] A fine tuning of the hydrogen bonding, electrostatic interactions and hydrophobic contacts is necessary for the suitable formation of the corresponding supramolecular ordered structures. Moreover, these second-generation GAPs showed improved self-assembling properties in aqueous media as compared to the first-generation GAPs previously reported, including the presence of smaller CAC values under similar conditions that can be up to one order of magnitude lower.[38-40] This better performance is maintained in different buffers and in the presence of salt, which paves the way toward the 
future application of these molecules in biological studies or pharmaceutical applications.[5,6,11,12,15,17,18,25-31,46,47,54]

\section{Conflict of Interest Statement}

The authors declare no competing financial interest.

Acknowledgements: Financial support has been provided by the Generalitat Valenciana (PROMETEO/2016/071) and the Spanish MINECO (CTQ2015-68429-R). A.H.L. thanks Generalitat Valenciana for a Grisolía fellowship. The technical support of the SCIC at the Universitat Jaume I is acknowledged.

\section{Appendix A. Supplementary material}

Supplementary data associated with this areticle can be found, in the online version at http://dx.doi.org/xxxxxxxxxxxxxxxxx

\section{References}

[1] S. Bera, E. Gazit, Self-assembly of Functional Nanostructures by Short Helical Peptide Building Blocks, Protein Pept. Lett. 26 (2019) 88-97. doi:10.2174/0929866525666180917163142.

[2] G. Qi, Y. Gao, L. Wang, H. Wang, Self-Assembled Peptide-Based Nanomaterials for Biomedical Imaging and Therapy, Adv. Mater. 30 (2018) 1703444. doi:10.1002/adma.201703444.

[3] T. Park, S.C. Zimmerman, Formation of a Miscible Supramolecular Polymer Blend through Self-Assembly Mediated by a Quadruply Hydrogen-Bonded Heterocomplex, J. Am. Chem. Soc. 128 (2006) 11582-11590. doi:10.1021/ja0631854.

[4] H. Faraji, R. Nedaeinia, E. Nourmohammadi, B. Malaekeh-Nikouei, H.R. Sadeghnia, S.P. Ziapour, H.K. Sarkarizi, R.K. Oskuee, A Review on Application of Novel Solid Nanostructures in Drug Delivery, J. Nano Res. 53 (2018) 22-36. doi:10.4028/www.scientific.net/JNanoR.53.22.

[5] G.M. Whitesides, Self-Assembly at All Scales, Science 295 (2002) 2418-2421. doi:10.1126/science.1070821.

[6] S. Li, R. Xing, R. Chang, Q. Zou, X. Yan, Nanodrugs based on peptide-modulated selfassembly: Design, delivery and tumor therapy, Curr. Opin. Colloid Interface Sci. 35 (2018) 17-25. doi:10.1016/j.cocis.2017.12.004.

[7] J.-M. Lehn, Toward Self-Organization and Complex Matter, Science 295 (2002) 24002403. doi:10.1126/science.1071063.

[8] L.P. Hernández-Eguía, R.J. Brea, L. Castedo, P. Ballester, J.R. Granja, Regioisomeric 
Control Induced by DABCO Coordination to Rotatable Self-Assembled Bis- and Tetraporphyrin $\alpha, \gamma$-Cyclic Octapeptide Dimers, Chem. - A Eur. J. 17 (2011) 1220-1229. doi:10.1002/chem.201002271.

[9] E. Gorrea, P. Nolis, E. Torres, E. Da Silva, D.B. Amabilino, V. Branchadell, R.M. Ortuño, Self-Assembly of Chiral trans -Cyclobutane-Containing $\beta$-Dipeptides into Ordered Aggregates, Chem. - A Eur. J. 17 (2011) 4588-4597. doi:10.1002/chem.201002193.

[10] R. Pugliese, A. Marchini, G.A.A. Saracino, R.N. Zuckermann, F. Gelain, Cross-linked selfassembling peptide scaffolds, Nano Res. 11 (2018) 586-602. doi:10.1007/s12274-0171834-6.

[11] M.J. Webber, E.A. Appel, E.W. Meijer, R. Langer, Supramolecular biomaterials, Nat. Mater. 15 (2016) 13-26. doi:10.1038/nmat4474.

[12] A. Mata, L. Hsu, R. Capito, C. Aparicio, K. Henrikson, S.I. Stupp, Micropatterning of bioactive self-assembling gels, Soft Matter. 5 (2009) 1228. doi:10.1039/b819002j.

[13] E. Torres, J. Puigmartí-Luis, Á. Pérez del Pino, R.M. Ortuño, D.B. Amabilino, Use of unnatural $\beta$-peptides as a self-assembling component in functional organic fibres, Org. Biomol. Chem. 8 (2010) 1661. doi:10.1039/b922843h.

[14] D.B. Amabilino, J. Puigmartí-Luis, Gels as a soft matter route to conducting nanostructured organic and composite materials, Soft Matter. 6 (2010) 1605. doi:10.1039/b923618j.

[15] S.I. Stupp, Self-Assembly and Biomaterials, Nano Lett. 10 (2010) 4783-4786. doi:10.1021/nl103567y.

[16] E. Gazit, Self-assembled peptide nanostructures: the design of molecular building blocks and their technological utilization, Chem. Soc. Rev. 36 (2007) 1263.

doi:10.1039/b605536m.

[17] S. Zhang, Fabrication of novel biomaterials through molecular self-assembly, Nat. Biotechnol. 21 (2003) 1171-1178. doi:10.1038/nbt874.

[18] R.J. Brea, C. Reiriz, J.R. Granja, Towards functional bionanomaterials based on selfassembling cyclic peptidenanotubes, Chem. Soc. Rev. 39 (2010) 1448-1456. doi:10.1039/B805753M.

[19] Y. Zhao, J. Wang, L. Deng, P. Zhou, S. Wang, Y. Wang, H. Xu, J.R. Lu, Tuning the SelfAssembly of Short Peptides via Sequence Variations, Langmuir. 29 (2013) 13457-13464. doi:10.1021/la402441w.

[20] J.N. Shera, X.S. Sun, Effect of Peptide Sequence on Surface Properties and SelfAssembly of an Amphiphilic pH-Responsive Peptide, Biomacromolecules. 10 (2009) 2446-2450. doi:10.1021/bm900388b.

[21] S. Ghosh, S. Verma, Solvent-mediated morphological transformations in peptide-based soft structures, Tetrahedron. 64 (2008) 6202-6208. doi:10.1016/j.tet.2008.05.003.

[22] R. García-Fandiño, J.R. Granja, M. Orozco, Theoretical Characterization of the Dynamical Behavior and Transport Properties of $\alpha, \gamma$-Peptide Nanotubes in Solution, J. Am. Chem. Soc. 131 (2009) 15678-15686. doi:10.1021/ja903400n. 
[23] G.P. Spada, S. Lena, S. Masiero, S. Pieraccini, M. Surin, P. Samorì, Guanosine-based Hydrogen-bonded Scaffolds: Controlling the Assembly of Oligothiophenes, Adv. Mater. 20 (2008) 2433-2438. doi:10.1002/adma.200703177.

[24] P. Pramod, K.G. Thomas, M. V. George, Organic Nanomaterials: Morphological Control for Charge Stabilization and Charge Transport, Chem. - An Asian J. 4 (2009) 806-823. doi:10.1002/asia.200900014.

[25] S. Cavalli, F. Albericio, A. Kros, Amphiphilic peptides and their cross-disciplinary role as building blocks for nanoscience, Chem. Soc. Rev. 39 (2010) 241-263. doi:10.1039/B906701A.

[26] N. Nandi, K. Gayen, S. Ghosh, D. Bhunia, S. Kirkham, S.K. Sen, S. Ghosh, I.W. Hamley, A. Banerjee, Amphiphilic Peptide-Based Supramolecular, Noncytotoxic, Stimuli-Responsive Hydrogels with Antibacterial Activity, Biomacromolecules. 18 (2017) 3621-3629. doi:10.1021/acs.biomac.7b01006.

[27] C.A. Machado, I.R. Smith, D.A. Savin, Self-Assembly of Oligo- and Polypeptide-Based Amphiphiles: Recent Advances and Future Possibilities, Macromolecules. 52 (2019) 1899-1911. doi:10.1021/acs.macromol.8b02043.

[28] J.D. Hartgerink, Self-Assembly and Mineralization of Peptide-Amphiphile Nanofibers, Science 294 (2001) 1684-1688. doi:10.1126/science.1063187.

[29] M.P. Hendricks, K. Sato, L.C. Palmer, S.I. Stupp, Supramolecular Assembly of Peptide Amphiphiles, Acc. Chem. Res. 50 (2017) 2440-2448. doi:10.1021/acs.accounts.7b00297.

[30] H. Cui, M.J. Webber, S.I. Stupp, Self-assembly of peptide amphiphiles: From molecules to nanostructures to biomaterials, Biopolymers. 94 (2010) 1-18. doi:10.1002/bip.21328.

[31] A. Iscen, G.C. Schatz, Peptide amphiphile self-assembly, EPL (Europhysics Lett. 119 (2017) 38002. doi:10.1209/0295-5075/119/38002.

[32] L.S. Birchall, S. Roy, V. Jayawarna, M. Hughes, E. Irvine, G.T. Okorogheye, N. Saudi, E. De Santis, T. Tuttle, A.A. Edwards, R. V. Ulijn, Exploiting $\mathrm{CH}-\pi$ interactions in supramolecular hydrogels of aromatic carbohydrate amphiphiles, Chem. Sci. 2 (2011) 1349. doi:10.1039/c0sc00621a.

[33] Y. Zhao, W. Yang, C. Chen, J. Wang, L. Zhang, H. Xu, Rational design and self-assembly of short amphiphilic peptides and applications, Curr. Opin. Colloid Interface Sci. 35 (2018) 112-123. doi:10.1016/j.cocis.2018.02.009.

[34] M.J. Krysmann, V. Castelletto, J.E. McKendrick, L.A. Clifton, P.J.F. Harris, S.M. King, SelfAssembly of Peptide Nanotubes in an Organic Solvent, Langmuir. 24 (2008) 8158-8162. doi:10.1021/la800942n.

[35] I. Alfonso, M. Bru, M.I. Burguete, E. García-Verdugo, S. V. Luis, Structural Diversity in the Self-Assembly of Pseudopeptidic Macrocycles, Chem. - A Eur. J. 16 (2010) 12461255. doi:10.1002/chem.200902196.

[36] S. Wang, R. Attah, J. Li, Y. Chen, R. Chen, A pH-responsive amphiphilic hydrogel based on pseudopeptides and poly (ethylene glycol) for oral delivery of hydrophobic drugs, ACS Biomater. Sci. Eng. 4 (2018) 4236-4243. doi:10.1021/acsbiomaterials.8b01040. 
[37] A. Skandalis, S. Pispas, $\mathrm{pH}$-and thermo-responsive solution behavior of amphiphilic, linear triblock terpolymers, Polymer 157 (2018) 9-18.

doi:10.1016/j.polymer.2018.10.023.

[38] J. Rubio, I. Alfonso, M.I. Burguete, S. V Luis, Interplay between hydrophilic and hydrophobic interactions in the self-assembly of a gemini amphiphilic pseudopeptide: from nano-spheres to hydrogels, Chem. Commun. 48 (2012) 2210. doi:10.1039/c2cc17153h.

[39] A.H. Lotfallah, M.I. Burguete, I. Alfonso, S. V Luis, Highly stable oil-in-water emulsions with a gemini amphiphilic pseudopeptide, RSC Adv. 5 (2015) 36890-36893. doi:10.1039/C5RA05121E.

[40] J. Rubio, I. Alfonso, M.I. Burguete, S. V. Luis, Stimulus responsive self-assembly of Gemini Amphiphilic Pseudopeptides, Soft Matter. (2011). doi:10.1039/c1sm06435e.

[41] L.-J. Chen, H.-B. Yang, Construction of stimuli-responsive functional materials via hierarchical self-assembly involving coordination interactions, Acc. Chem. Res. 51 (2018) 2699-2710. doi:10.1021/acs.accounts.8b00317.

[42] T. Kakuta, T. Yamagishi, T. Ogoshi, Stimuli-Responsive Supramolecular Assemblies Constructed from Pillar[ $\mathrm{n}$ ]arenes, Acc. Chem. Res. 51 (2018) 1656-1666. doi:10.1021/acs.accounts.8b00157.

[43] A. Shah, M.S. Malik, G.S. Khan, E. Nosheen, F.J. Iftikhar, F.A. Khan, S.S. Shukla, M.S. Akhter, H.-B. Kraatz, T.M. Aminabhavi, Stimuli-responsive peptide-based biomaterials as drug delivery systems, Chem. Eng. J. (2018). doi:10.1016/j.cej.2018.07.126.

[44] A. Dehsorkhi, V. Castelletto, I.W. Hamley, Self-assembling amphiphilic peptides, J. Pept. Sci. 20 (2014) 453-467. doi:10.1002/psc.2633.

[45] N. Molchanova, P. Hansen, H. Franzyk, Advances in development of antimicrobial peptidomimetics as potential drugs, Molecules. 22 (2017) 1430. doi:10.3390/molecules22091430.

[46] R. V Ulijn, A.M. Smith, Designing peptide based nanomaterials, Chem. Soc. Rev. 37 (2008) 664. doi:10.1039/b609047h.

[47] K. Andreev, M.W. Martynowycz, M. Lingaraju, C. Bianchi, A. Mor, D. Gidalevitz, Antimicrobial Peptidomimetics with Activity Towards Cancer Cells, Biophys. J. 116 (2019) 86a. doi:10.1016/j.bpj.2018.11.505.

[48] X. Zhao, S. Zhang, Molecular designer self-assembling peptides, Chem. Soc. Rev. 35 (2006) 1105. doi:10.1039/b511336a.

[49] R. Kuppusamy, M. Yasir, T. Berry, C.G. Cranfield, S. Nizalapur, E. Yee, O. Kimyon, A. Taunk, K.K.K. Ho, B. Cornell, Design and synthesis of short amphiphilic cationic peptidomimetics based on biphenyl backbone as antibacterial agents, Eur. J. Med. Chem. 143 (2018) 1702-1722. doi:10.1016/j.ejmech.2017.10.066.

[50] N. Amdursky, M. Molotskii, E. Gazit, G. Rosenman, Elementary Building Blocks of SelfAssembled Peptide Nanotubes, J. Am. Chem. Soc. 132 (2010) 15632-15636. doi:10.1021/ja104373e.

[51] I. Imaz, M. Rubio-Martínez, W.J. Saletra, D.B. Amabilino, D. Maspoch, Amino Acid Based 
Metal-Organic Nanofibers, J. Am. Chem. Soc. 131 (2009) 18222-18223.

doi:10.1021/ja908721t.

[52] K. Lu, L. Guo, A.K. Mehta, W.S. Childers, S.N. Dublin, S. Skanthakumar, V.P. Conticello, P. Thiyagarajan, R.P. Apkarian, D.G. Lynn, Macroscale assembly of peptide nanotubes, Chem. Commun. (2007) 2729. doi:10.1039/b701029j.

[53] E. Faggi, S. V. Luis, I. Alfonso, Sensing, transport and other potential biomedical applications of pseudopeptides, Curr. Med. Chem. 26 (2019) 4065-4097. doi:10.2174/0929867325666180301091040.

[54] R. Pugliese, F. Gelain, Peptidic Biomaterials: From Self-Assembling to Regenerative Medicine, Trends Biotechnol. 35 (2017) 145-158. doi:10.1016/j.tibtech.2016.09.004.

[55] J. Rubio, I. Alfonso, M. Bru, M.I. Burguete, S. V. Luis, Gemini amphiphilic pseudopeptides: synthesis and preliminary study of their self-assembling properties, Tetrahedron Lett. 51 (2010) 5861-5867. doi:10.1016/j.tetlet.2010.07.146.

[56] E. Faggi, A. Moure, M. Bolte, C. Vicent, S. V. Luis, I. Alfonso, Pseudopeptidic cages as receptors for N-protected dipeptides, j. Org. Chem. 79 (2014) 4590-4601. doi:10.1021/jo500629d.

[57] A. Ajayaghosh, R. Varghese, S. Mahesh, V.K. Praveen, From Vesicles to Helical Nanotubes: A Sergeant-and-Soldiers Effect in the Self-Assembly of Oligo ( $p$ phenyleneethynylene) s, Angew. Chemie Int. Ed. 45 (2006) 7729-7732. doi:10.1002/anie.200603238.

[58] X. Yan, Q. He, K. Wang, L. Duan, Y. Cui, J. Li, Transition of cationic dipeptide nanotubes into vesicles and oligonucleotide delivery, Angew. Chemie Int. Ed. 46 (2007) 2431-2434. doi:10.1002/anie.200603387.

[59] S.R. Diegelmann, J.M. Gorham, J.D. Tovar, One-dimensional optoelectronic nanostructures derived from the aqueous self-assembly of $\pi$-conjugated oligopeptides, J. Am. Chem. Soc. 130 (2008) 13840-13841. doi:10.1021/ja805491d.

[60] A. Tinti, M. Di Foggia, P. Taddei, A. Torreggiani, M. Dettin, C. Fagnano, Vibrational study of auto-assembling oligopeptides for biomedical applications, J. Raman Spectrosc. 39 (2008) 250-259. doi:10.1002/jrs.1867.

[61] A.P. Mendham, T.J. Dines, M.J. Snowden, R. Withnall, B.Z. Chowdhry, IR/Raman spectroscopy and DFT calculations of cyclic di-amino acid peptides. Part III: comparison of solid state and solution structures of cyclo (L-Ser-L-Ser), J. Raman Spectrosc. 40 (2009) 1508-1520. doi:10.1002/jrs.2306.

[62] A. Barth, Infrared spectroscopy of proteins, Biochim. Biophys. Acta (BBA)-Bioenergetics. 1767 (2007) 1073-1101. doi:10.1002/0470027320.

[63] L. De Marco, M. Thämer, M. Reppert, A. Tokmakoff, Direct observation of intermolecular interactions mediated by hydrogen bonding, J. Chem. Phys. 141 (2014) 07B612_1. doi:10.1063/1.4885145.

[64] W. Herrebout, K. Clou, H.O. Desseyn, N. Blaton, Vibrational characterization of the peptide bond, Spectrochim. Acta Part A Mol. Biomol. Spectrosc. 59 (2003) 47-59. doi:10.1016/S1386-1425(02)00112-9. 
[65] B. Korchowiec, M. Gorczyca, J. Korchowiec, J. Rubio-Magnieto, A.H. Lotfallah, S. V Luis, E. Rogalska, The effect of protonation in a family of peptide based gemini amphiphiles on the interaction in Langmuir films, J. Mol. Liq. 284 (2019) 357-365.

doi:doi.org/10.1016/j.molliq.2019.03.177.

[66] B. Korchowiec, M. Gorczyca, J. Korchowiec, J. Rubio-Magnieto, A.H. Lotfallah, S. V Luis, E. Rogalska, Structure-membrane activity relationship in a family of peptide-based gemini amphiphiles: An insight from experimental and theoretical model systems, Colloids Surfaces B Biointerfaces. 146 (2016) 54-62.

doi:10.1016/j.colsurfb.2016.05.040.

[67] M. Gorczyca, B. Korchowiec, J. Korchowiec, S. Trojan, J. Rubio-Magnieto, S. V Luis, E. Rogalska, A study of the interaction between a family of gemini amphiphilic pseudopeptides and model monomolecular film membranes formed with a cardiolipin, J. Phys. Chem. B. 119 (2015) 6668-6679. doi:10.1021/acs.jpcb.5b02575.

[68] J. Rubio-Magnieto, S. V Luis, M. Orlof, B. Korchowiec, G. Sautrey, E. Rogalska, Effects of gemini amphiphilic pseudopeptides on model lipid membranes: A Langmuir monolayer study, Colloids Surfaces B Biointerfaces. 102 (2013) 659-666.

doi:10.1016/j.colsurfb.2012.09.023.

[69] H.S. Kim, J.D. Hartgerink, M.R. Ghadiri, Oriented self-assembly of cyclic peptide nanotubes in lipid membranes, J. Am. Chem. Soc. 120 (1998) 4417-4424. doi:10.1021/ja9735315.

[70] M.C. Hull, L.R. Cambrea, J.S. Hovis, Infrared spectroscopy of fluid lipid bilayers, Anal. Chem. 77 (2005) 6096-6099. doi:10.1021/ac050990c.

[71] J. Aguiar, P. Carpena, J.A. Molina-Bolıvar, C.C. Ruiz, On the determination of the critical micelle concentration by the pyrene 1: 3 ratio method, J. Colloid Interface Sci. 258 (2003) 116-122. doi:10.1016/S0021-9797(02)00082-6. 